\title{
Diagnostic problems and prognostic factors in prostate cancer
}

\author{
Ph.D. Thesis \\ Miklós Tarján, M.D. \\ Supervisor: \\ Prof. Gábor Cserni, M.D., Ph.D., D.Sc. \\ Department of Pathology, University of Szeged
}

Department of Pathology and Clinical Cytology, Central Hospital, Falun, Sweden

Szeged

2013 
This thesis is dedicated to

the memory of my father, vitéz dr. Tarján Jenő (1935-2013),

Who has dedicated his life to cure people...

...for inspiring my fascination in science. 


\section{List of full papers that served as the basis of the Ph.D. thesis:}

I. Tarján M, Tot T. Prediction of extracapsular extension of prostate cancer based on systematic core biopsies. Scand J Urol Nephrol 2006;40:459-64. IF(2006): 1,089

II. Tarján M. Prognostic significance of focal neuroendocrine differentiation in prostate cancer: cases with autopsy-verified cause of death. Indian J Urol 2010;26:41-45.

III. Tarján M, Lenngren A, Hellberg D, Tot T. Immunohistochemical verification of ductal differentiation in prostate cancer. APMIS 2012;120:510-18. IF(2012): 2,068

IV. Tarján M, Chen H-H, Tot T, Wu W, Lenngren A, Dean PB, Tabár L. Improved differentiation between ductal and acinar prostate cancer using 3-dimensional histology and biomarkers. Scand J Urol Nephrol 2012;46:258-66. IF(2012): 1,007

\section{Others publications:}

1. Tarján M, Cserni G. Tüdőembólia a patológus szemével. A gyakoriság, szezonalitás megítélése és a klinikai felismerés elemzése. Cardiologia Hungarica 1999;18(2):6165.

2. Cserni G, Vajda K, Tarján M, Bori R, Svébis M, Baltás B. Nodal staging of colorectal carcinomas from quantitative and qualitative aspects. Can lymphatic mapping help staging? Pathol Oncol Res 1999;5:291-296.

3. Cserni G, Tarján M. Prosztata szövet az ovarium dermoid cystájában. Orv Hetil. 2000;141:355-356. 
4. Cserni G, Tarján M, Bori R. Distance of lymph nodes from the tumor, an important feature in colorectal cancer specimens. Arch Pathol Lab Med 2001;125:246-249. IF(2001): 1,257

5. Tarján M, Cserni G, Szabó Z. Malignant fibrous histiocytoma of the kidney. Scan J Urol Nephrol 2001;53:518-520. IF(2001): 0,722

6. Tarján M, Cserni G, Szabó Z. Malignus fibrosus histiocytoma a vesében. Magyar Urológia 2001;13:188-194.

7. Cserni G, Kovács RB, Tarján M, Sápi Z, Domján Z, Szabó Z. Sarcomatoid renal cell carcinoma with foci of chromophobe carcinoma. Pathol Oncol Res 2002;8:142-144.

8. Vajda K, Cserni G, Svébis M, Baltás B, Bori R, Tarján M, Kocsis L. Sentinel nyirokcsomó meghatározása vastagbélrákok esetén. Magyar Sebészet 2002;55:375377.

9. Tarján M. Őrszem nyirokcsomó-biopszia Magyarországon. A sebészi onkologia forradalmi újitásának hazai eredményei. Magy Onkol. 2002;46:315-21

10. Tarján M, Sápi Z, Bentzik A, Cserni G. Egy ritka uterusmalignoma: adenosarcoma endometrii. Lege Artis Medicinae 2004;14:598-600.

11. Cserni G, Burzykowski T, Vinh-Hung V, Kocsis L, Boross G, Sinkó M, Tarján M, Bori R, Rajtár M, Tekle E, Maráz R, Baltás B, Svébis M. Axillary sentinel node and tumour-related factors associated with non-sentinel node involvement in breast cancer. Jpn J Clin Oncol 2004;34:519-524. IF(2004): 0,96

12. Tarján M, Sarkissov G, Tot T. Unclassified sex cord/gonadal stromal testis tumor with predominance of spindle cells. APMIS 2006;114:465-469. IF(2006): 1,875 
13. Sebők J, Tarján M. [Discrepancies between clinical and pathological diagnosesmethods and pitfalls.] Orv Hetil 2008;149:1125-1135.

14. Tarján M, Ottlecz I, Tot T. Primary adenocarcinoma of the seminal vesicle. Indian J Urol 2009;25:143-145.

15. Tot T, Pekár G, Hofmeyer S, Sollie T, Gere M, Tarján M. The distribution of lesions in 1-14-mm invasive breast carcinomas and its relation to metastatic potential. Virchows Arch 2009;455:109-115. IF(2009): 2,305

16. Tot T, Pekár G, Hofmeyer S, Gere M, Tarján M, Hellberg D, Lindquist D. Molecular phenotypes of unifocal, multifocal, and diffuse invasive breast carcinomas. Pathol Res Int 2011; 2011:480960.

17. Tot T, Gere M, Pekár G, Tarján M, Hofmeyer S, Hellberg D, Lindquist D, Chen TH, Yen AM, Chiu SY, Tabár L. Breast cancer multifocality, disease extent, and survival. Hum Pathol 2011;42:1761-1769. IF(2011): 2,876

18. Lindquist D, Ahrlund-Richter A, Tarján M, Tot $T$, Dalianis $T$. Intense CD44 expression is a negative prognostic factor in tonsillar and base of tongue cancer. Anticancer Res 2012; 32(1):153-61. IF(2011): 1,725

19. Pekár Gy, Hofmeyer S, Tabár L, Tarján M, Chen H-H, Yen AM, Chiu SH, Hellberg D. Gere M, Tot T. Multifocal breast cancer documented in large-format histology sections. Cancer 2013;119(6):1132-9. IF(2011): 4,771

\section{Abstracts:}

1. Tarján M, Cserni G. Esophagogastric varices - is there a relationship between their rupture and vessels of the ligamentum falciforme hepatis or changes of the seasons? Virchows Archiv 1999; 435(3):356. 
2. Cserni G, Burzykowski T, Vinh-Hung V, Boross G, Sinkó M, Svébis M, Tarján M, Bori R, Kocsis L, Rajtar M, Tekle EW, Baltás B. Sentinel node biopsy based factors associated with non-sentinel node involvement in breast cancer. J Jpn Surg Soc 2003;104:575.

\section{Presentations:}

1. 6th Meeting of Hungarian Urologists in Kecskemét, 15-17 May 1997 (oral presentation) Cserni G, Tarján M: Tumoros vagy arra gyanús húgyhólyagminták hisztológiája (1994-1996)- Megoszlás és a leletek első auditja.

2. 1st Bács-Kiskun County Meeting of Young Hungarian Medical Doctors, Kecskemét 14 Nov 1997 (oral presentation) - Molnár B, Tarján M: Felnőttkori óriássejtes hepatitis esetismertetés kapcsán.

3. Meeting of Young Pathologists 1998. (oral presentation), Congress of Hungarian Pathologists, Gyula 26-29 Aug 1998 (poster) Tarján M: A halálos tüdőembólia és a heveny szívizominfarktus szezonalitása.

4. 5th Congress of Hungarian Group of Thrombosis and Haemostasis, Bükfürdö, Nov 1998 (poster) Tarján M: Tüdőembólia a patológus szemével.

5. 7th Meeting of Hungarian Urologists, Kecskemét, 28-30 May 1999 (oral presentation) Tarján M: A férfiak privilégiuma-e a prosztata?

6. Meeting of Young Pathologists 2000. (oral presentation), Tarján M: A colorectalis carcinomák nodalis statusának meghatározása. - A nyirokcsomók lokalizációjának jelentősége

7. Congress of Hungarian Pathologists, Eger, 21-24 Sept 2000 (poster) Tarján M: Malignus fibrosus histiocytoma vesében 
8. Congress of Hungarian Pathologists, Kaposvár, 30 Aug-2 Sept 2001 (poster) Tarján M: Az AGUS klinikai jelentősége

9. Meeting of Young Pathologists, Győr, 2002 (oral presentation) Tarján M: Tüdőembólia profilaxis a kórházunk gyakorlatában

10. Congress of Hungarian Pathologists, Siófok, Sept 2004, (poster) Tarján M: Egy ritka uterus malignoma: Adenosarcoma endometrii

11. Europrevent Congress, 6-9 May 2009, Stockholm ( poster) Tarján J, Tarján M : Correlation between the severity of atherosclerosis in coronary and carotid arteries in autopsy verified study. 
Table of contents

LIST OF FIGURES.................................................... 9

LIST OF TABLES............................................... 10

LIST OF ABBREVIATIONS....................................... 11

1. INTRODUCTION ................................................... 12

2. AIMS....................................................... 18

3.3 PATIENTS AND METHODS................................. 18

3.1 Study population............................................... 18

3.2 Histological examination......................................... 19

3.3 Immunohistochemistry.......................................... 24

3.4 Statistical analysis of the biomarker study....................... 26

3.5 Statistical analysis of the ECE study.............................. 27

3.6 Ethics.......................................................... 27

4. RESULTS....................................................... 27

4.1 Comparison of DAP with AAP.................................. 27

4.2 Analysis of potential biomarkers of poor prognosis................. 29

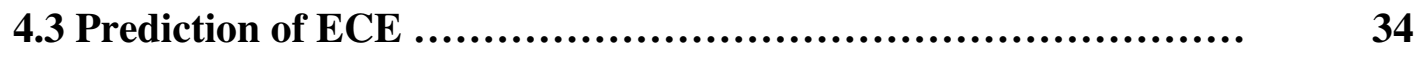

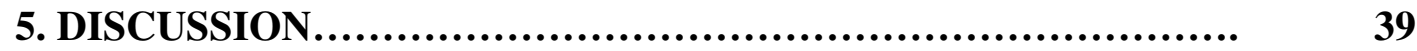

6. SUMMARY, CONCLUSIONS.................................. 48

ACKNOWLEDGEMENTS............................................ 49

REFERENCES................................................... 50

SUPPLEMENTS...................................................... 58 


\section{LIST OF FIGURES}

- Figure 1. The distribution of the incidence and mortality of malignant tumours in Hungary and in Sweden. (page 13.)

- Figure 2..Incidence and mortality rates of PCa in Sweden between 1960-2008. (page 14.)

- Figure 3. Large-section histology image of a prostate slice with three positive core biopsies and three negative cores. (page 20.)

- Figure 4. The basic growth patterns in acinar and ductal (cribriform, papillary and PIN-like, and solid) prostate cancers. (page 21.)

- Figure 5. Thick large-format (3D) histology section of a prostatectomy specimen (a); the corresponding two-dimensional (2D) large-format slide (b); comedo growth pattern in DAP in 3D (c) and 2D (d) histology; papillary DAP in 3D (e) and 2D (f) histology; pure cribriform growth pattern in DAP in 3D $(\mathrm{g})$ and 2D $(\mathrm{h})$ histology; AAP for comparison, 3D (i) and 2D (j) histology. (page 23.)

- Figure 6. Immunohistochemical p53 expression: absent in AAP (a), present in DAP (b); chromogranine A expression: few positively stained cells in AAP (c), numerous in DAP (d); EGFR expression absent in the AAP (e), present in DAP (f). (page 32.)

- Figure 7. Receiver operating characteristic (ROC) curve for the discriminatory power of the combined biomarkers Chromogranin A, EGFR and p53 percentage. (page 34.)

- Figure 8. Side-for-side (168 sides) analysis of at least sextant biopsies showing a significant association between the number of positive biopsy cores per side and the finding of ECE at RP. (page 35.)

- Figure 9. Dominant side (84 sides) analysis demonstrating an association between the number of positive biopsy cores per side and finding of ECE at RP. (page 36.)

- Figure 10. Relationship between the preoperative PSA level and the presence of ECE at RP (page 38.)

- Figure 11. Relationship between the biopsy Gleason score and the presence of ECE at RP (page 38.)

- Figure 12. Relationship between the combination of three prognostic parameters (number of positive biopsies, preoperative PSA level and biopsy Gleason score) and 
the presence of ECE at RP. The high-risk parameters are: number of positive biopsies $>1$; Gleason score 7 or more; serum PSA $>10 \mathrm{ng} / \mathrm{ml}$. (page 39.)

\section{LIST OF TABLES}

- Table 1. Prognostic factors for prostate cancer: College of American Pathologists (CAP) and World Health Organization (WHO) (page 15.)

- Table 2. List of primary antibodies used in the present study and the basic technical parameters. (page 25.)

- Table 3. The clinical and pathological characteristics of the prostate cancer patients according to the presence or absence of a ductal component (page 28.)

- Table 4. Unadjusted and adjusted odds ratios of immunohistochemical markers to distinguish pure acinar adenocarcinoma (AAP) of the prostate from ductal/mixed ductal-acinar type adenocarcinoma (DAP) of the prostate on the basis of 110 total prostatectomy specimens. (page 30.)

- Table 5. The predictive value of the three selected biomarkers in 24 preoperative core biopsy cases (page 33.)

- Table 6. Results of the side-for-side analysis in predicting ECE. (page 37.)

- Table 7. Results of the dominant side analysis in predicting ECE. (page 37.)

- Table 8. Survey of DAP related literature from PubMed including papers published between 1982 - 2011. (page 41.)

- Table 9. Risk groups of prostate cancer, based on the correlation between preoperative diagnostic parameters and 10-year cancer-free survival after RP according to D`Amico (page 46.) 


\section{LIST OF ABBREVIATIONS}

3D

three dimensional

AAP acinar adenocarcinoma of the prostate

AMACR alpha-methylacyl-coenzyme A racemase

ASR age-standardized rate

AUC area under the curve

CAP College of American Pathologists

DAP ductal adenocarcinoma of the prostate / adenocarcinoma of the prostate with ductal component

ECE extracapsular extension

EGFR epidermal growth factor receptor

NED neuroendocrine differentiation

PCa prostate cancer

PIN prostatic intraepithelial neoplasia

PSA prostate specific antigen

PSAP prostate-specific acid phosphatase

ROC receiver-operating characteristic

RP radical prostatectomy

TMA tissue microarray

WHO World Health Organization 


\section{INTRODUCTION}

Prostate cancer $(\mathrm{PCa})$ is the most frequently diagnosed cancer of men (899 000 new cases, $13.6 \%$ of the total) and the fifth most common cancer overall. Nearly three quarters of the registered cases occur in developed countries (644 000 cases). Incidence rates of PCa vary by more than 25-fold worldwide, the highest rates being in Australia/New Zealand (104.2 per 100,000) (1), Western and Northern Europe, Northern America. This is largely due to the widespread use of non-organized screening with prostate specific antigen (PSA) testing and subsequent biopsy in these regions. Incidence rates are relatively high in certain developing regions such as the Caribbean, South America and sub-Saharan Africa. With an estimated 258 000 deaths in 2008, PCa is the sixth leading cause of death from cancer in men $6.1 \%$ of the total) (1). Because PSA testing has a much greater effect on incidence than on mortality, there is less variation in mortality rates worldwide (10-fold) than in incidence rates, and the number of deaths from $\mathrm{PCa}$ is almost the same in developed and developing regions. Mortality rates are generally high in predominantly black populations (Caribbean, 26.3 per 100,000 and subSaharan Africa, Age-Standardized rates (ASRs): 18-19 per 100,000), very low in Asia (ASR 2.5 per 100,000 in Eastern Asia for example) and intermediate in Europe and Oceania (1).

PCa was the first most frequently diagnosed cancer of men in Sweden and it was the third in rank in Hungary after lung and colorectal cancer in 2008. The same ranking could be seen in the mortality data at this time (Figure 1). 


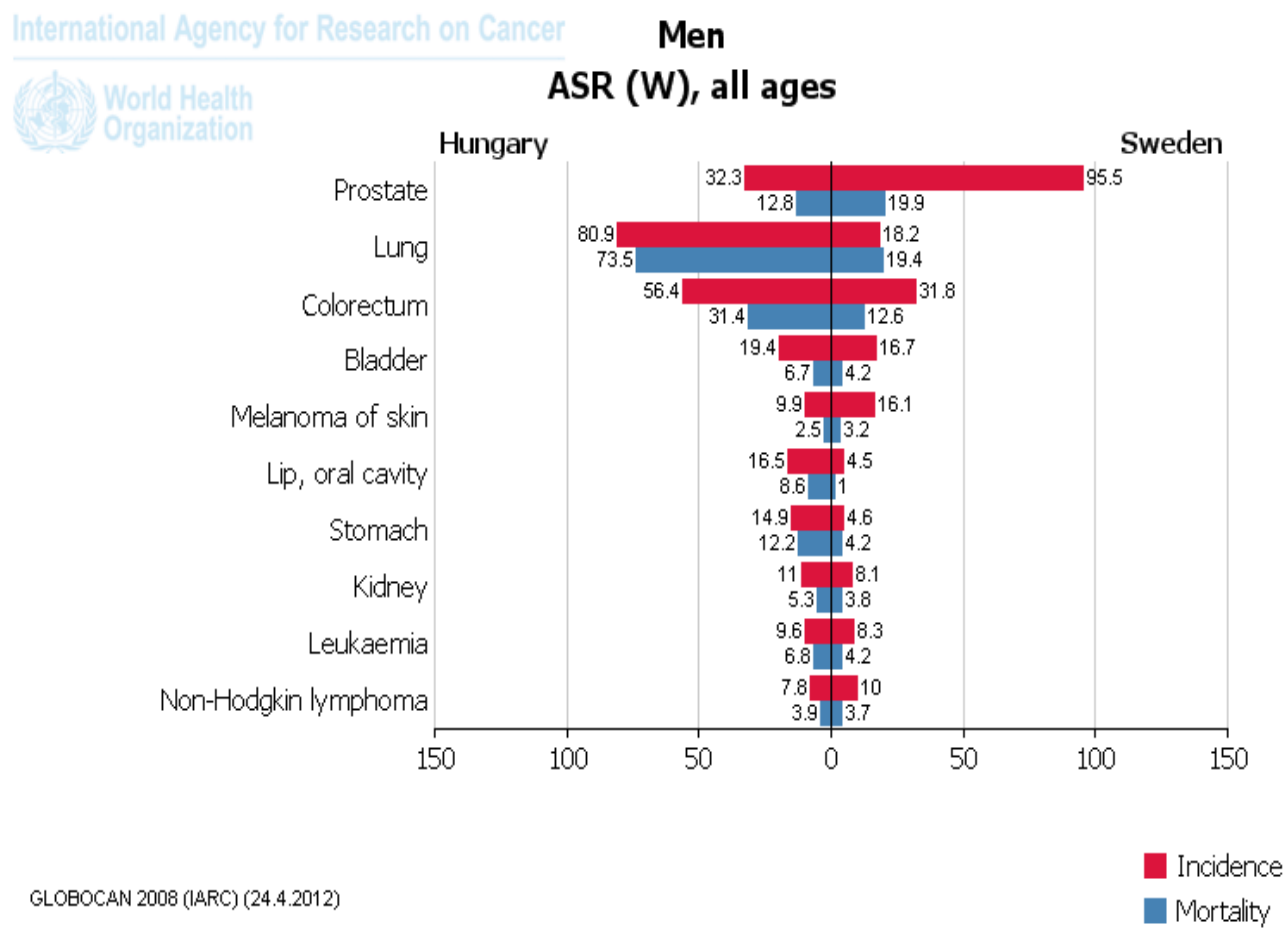

Figure 1. The distribution of the incidence and mortality of malignant tumours in Hungary and in Sweden.

A rapid increase of incidence of PCa has been observed in Sweden since the 1990s while the rate of mortality remained unchanged (Figure 2). During the same period, the increase of incidence in Hungary was less marked than in Sweden, and the mortality rate was lower and stable (1). 


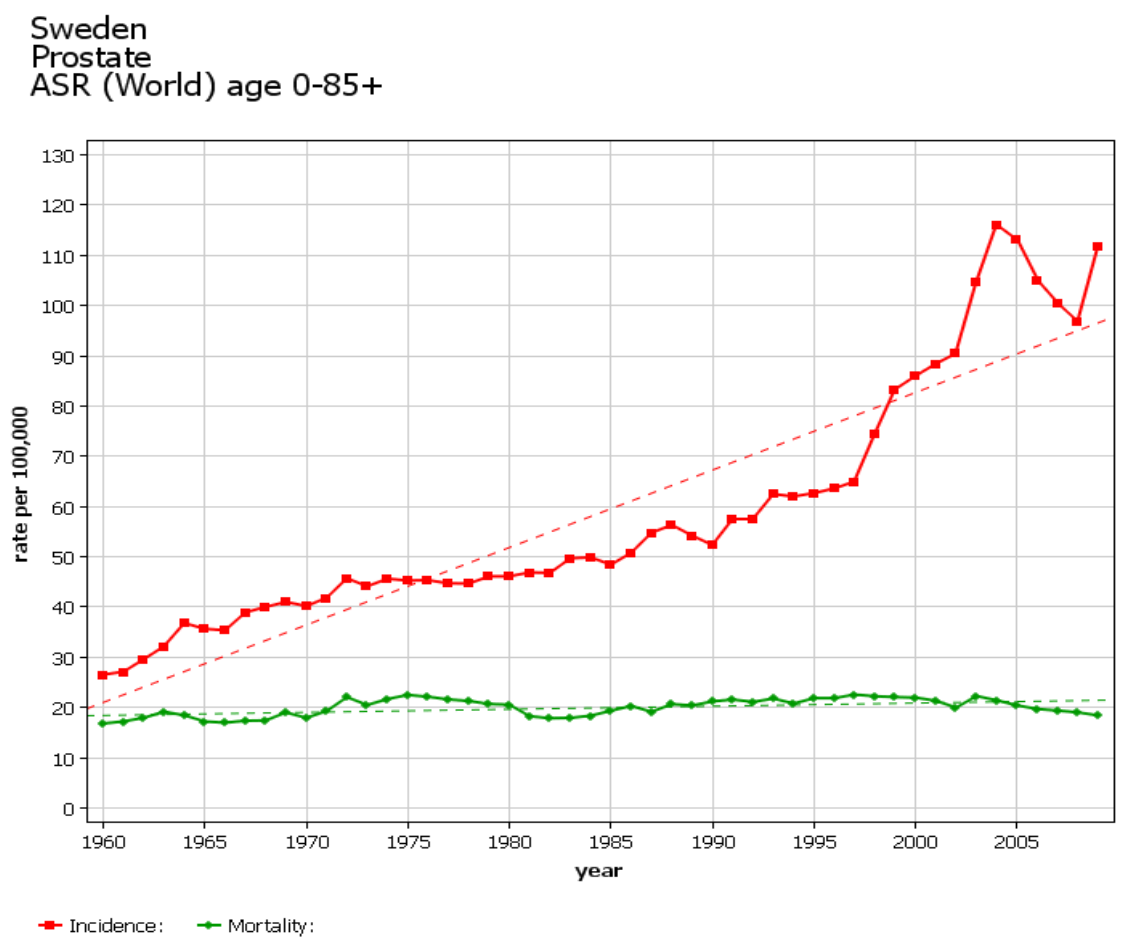

NORDCAN @ Association of the Nordic Cancer Registries (24.4.2012)

Figure 2. Incidence and mortality rates of PCa in Sweden between 1960-2008.

As a result of PSA screening, the majority of patients with PCa are diagnosed with potentially curable disease. Another consequence of screening is that the mean age of patients with this disease has diminished; $\mathrm{PCa}$ is no longer a disease of the elderly but is increasingly seen in middle aged men. Furthermore, screening leads to the down-staging of the disease with an increase in the number of organ-confined tumours, curable with radical prostatectomy (RP), a surgical treatment being increasingly offered (2).

Treatment of PCa with RP, radiotherapy and anti-androgen therapy results in prolonged long term survival in patient with localized and androgen-dependent PCa. Various treatment options are currently available for localized disease, including RP, conformal (threedimensional) external beam radiation, brachytherapy and other types of local therapy $(3,4)$. By contrast, hormone-refractory PCas are associated with disease relapse and poor survival.

A better understanding of the biological heterogeneity of the disease and reliable prognostic markers are needed to plan the therapy adequately and avoid over- or under-treatment. Prognosis for patients with PCa may be defined as the prediction of future behaviour of 
established malignancy, either in the absence of or after the application of therapy (5). Factors associated with outcome may be divided into two categories:

1. Prognostic factors: those that predict relapse or progression independently of future treatment effects.

2. Predictive factors: those that predict response or resistance to a specific treatment.

Currently, there are no predictive factors or markers utilized in PCa. For example, unlike breast carcinoma oestrogen receptor status, which can be used to predict response to hormonal treatment with tamoxifen, androgen receptor status in prostatic carcinoma does not predict response to hormonal therapy. Here, we briefly focus on prognostic factors, with stratification into categories of established factors recommended for routine reporting (category I), factors with promise or recommended despite incomplete data (category II), and factors that are not currently recommended due to insufficient evidence (category III) (Table 1.) $(6,7)$.

Category I: Recommended for routine reporting (7)

TNM based stage

Histological grade (Gleason)

Surgical margin status

Perioperative serum PSA

Category II: Factors with promise or recommended despite incomplete data DNA ploidy

Histologic type

Tumour amount in needle biopsy tissue

Tumour amount in RP specimens (correlates with extracapsular disease)

Category III: Not recommended due to insufficient evidence

Genetic markers

Neuroendocrine markers

Proliferation markers, apoptosis

Perineural invasion

Vascular/lymphatic invasion

Microvessel density

Nuclear morphometry

Androgen receptors

Age

Table 1. Prognostic factors for prostate cancer: College of American Pathologists (CAP) and World Health Organization (WHO) (6) 
Category I histopathological factors include pathologic stage and surgical margin status of radical prostatectomy specimens, and Gleason histological grade in all prostatic tissue samples. The best established prognostic parameter, the Gleason score is a widely accepted scoring system, the prognostic significance of which has been repeatedly proven (8), but it is also subject to considerable inter-observer variability, indicating the need for additional or alternative prognostic parameters.

Category II factors that are recommended for reporting include histologic subtypes of PCa and tumour amount in needle biopsy and RP specimens. The tumour amount in needle biopsy tissue may be reported in quantities such as the number of positive cores out of total number of cores, total length $(\mathrm{mm})$ of tumour in all cores, greatest percentage of a single core involved by carcinoma, and total or overall percentage of biopsy tissue involvement (which can be assessed by simple visual inspection). Data exist to suggest that it may be relevant to report more than one measure of tumour extent in needle biopsy tissue $(9,10)$. For RP specimens, it has been recommended to report tumour size as a percentage of cancer in the prostate (6) Additionally, one could measure size of a dominant nodule in two dimensions and indicate the number of blocks involved by tumour over the total number of blocks submitted (11). DNA ploidy was also put into category II, but currently it is felt that the data are not compelling enough to warrant its routine use (6). The probability of extracapsular disease most likely correlates with increasing tumour volume (12). The presence of extracapsular extension (ECE) in RP has been shown to have a significant negative impact on both biochemical and clinical failure rates (13). Therefore, accurate prediction of ECE is crucial when planning adequate treatment. Many predictive models using different preoperative parameters have been developed to promote this process (14-16). Number of positive (tumour-containing) biopsies and percent of cores containing cancer in prostate biopsy may be useful clinical parameters in identifying patients at high risk for ECE $(17,18)$.

Category III factors are not currently recommended for reporting due to insufficient evidence.

The prognostic significance of ductal differentiation in PCa was shown in a number of recent studies, indicating that tumours exhibiting this feature are more aggressive than their conventional acinar counterparts (19-23). Ductal adenocarcinoma of the prostate (DAP) is rare in its pure form and accounts for $0.4-1 \%$ of PCas (24), but focal ductal differentiation in common acinar PCa is observed in up to $5 \%$ of radical prostatectomy specimens (25). The 
proportion of tumour showing ductal differentiation that confers a prognostic difference remains controversial, but it is becoming more and more evident that identifying ductal differentiation in PCa and delineating these cases from pure acinar adenocarcinoma of the prostate (AAP) is an essential diagnostic task (19-21).

The role of immunohistochemistry in the diagnosis, differential diagnosis and prognostication of $\mathrm{PCa}$ is well documented in the literature, although it is mainly limited to prove the infiltrative nature of the lesions and/or their prostatic origin (26-28). The role of immunohistochemical markers in distinguishing different subtypes of PCa is a less explored area. Some reports indicate that neuroendocrine differentiation (NED) in the tumour is a significant prognostic parameter associated with shortened survival after endocrine therapy (29-31). A number of studies have analysed Ki67, p53, or bcl-2 expression in PCa, mostly in the context of prognosis (32-34). DAP expressing PSA and prostate-specific acid phosphatase (PSAP) may also show residual staining for high molecular weight cytokeratins and p63, and $70 \%$ express alpha-methylacyl-CoA racemase (AMACR) (24). These immunohistochemical features are, however, very similar to those in AAP, and are of no diagnostic value in distinguishing tumours showing ductal differentiation from pure AAP.

Our department's experience with large format thick histology sections (subgross, "three dimensional" /3D/ pathology) of breast tissue during the past two decades has confirmed the ability of this technique to reliably differentiate between acinar (lobular) and ductal structural components of normal and pathologic breast tissue (35-37). Although the subgross (3D) histology technique has been used to study diseases of the prostate (38), we have found no reports using this technique to determine the ductal or acinar origin or differentiation of prostate cancer. Having to distinguish DAP from AAP, we studied 3D thick section histology of prostatectomy specimens in addition to reviewing all the archived standard histological material. 


\section{AIMS}

The aims of the thesis are as follows:

2.1 to evaluate whether patients with PCa exhibiting ductal differentiation (DAP) have an unfavourable prognosis compared to those with pure AAP;

2.2 to evaluate the expression of nine immunohistochemical markers as prognostic predictors and their value in delineating carcinomas with and without ductal differentiation;

2.3 to refine the histological methodology for discriminating between DAP and AAP and explore whether these results have any therapeutic consequence;

2.4 to evaluate the clinical utility of transrectal ultrasound-guided systematic sextant or octant biopsies in the prediction of ECE at RP;

2.5 to find a useful combination of prognostic parameters in planning adequate therapy.

\section{PATIENTS AND METHODS}

\subsection{Study population}

The study population consisted of 110 patients treated with RP at Falun Central Hospital, Sweden, between January 2000 and December 2006. In 21 of these cases bilateral pelvic lymphadenectomy was also performed. Each patient underwent preoperative examinations according to a standardized protocol for preoperative disease staging. All PCas were considered to be organ-confined at the time of RP.

The following additional information was collected and analysed for this study: preoperative, postoperative and most recent serum PSA values, the adjuvant therapeutic regimens used, including hormone therapy, total androgen blockade, administration of radiotherapy and/or chemotherapy. Recurrence of the disease in this study was defined as histologically proven 
local recurrence, loco-regional lymph node recurrence, development of distant metastases or biochemical recurrence (PSA level $\geq 0.2 \mathrm{ng} / \mathrm{ml})(39)$.

In an earlier phase of the study (January 2000- August 2005) we analysed 84 cases with ultrasound-directed systematic sextant (three biopsies per side; i.e. apex mid gland, base) biopsies in 60 cases and systematic octant (four biopsies per side; ie, apex, mid-lateral and mid-medial gland, base) biopsies in 24 cases.

\subsection{Histological examination}

The prostatectomy specimens were histologically evaluated using multi-level large-format whole-mount cross-sections over the entire specimen (3 to 8 large-format blocks per case). Our large-section histology technique employs standard 10x8 cm object glasses while the size of the paraffin blocks is adjusted to the size of the prostatectomy specimens. This enables assessment of tumour multifocality, individual lesion size, capsular involvement (ECE) and also involvement of the seminal vesicles, which are included with the entire prostate gland on the sections (Figure 3). The complete material (84 preoperative biopsies and 110 prostatectomy specimens) was retrospectively reviewed. 

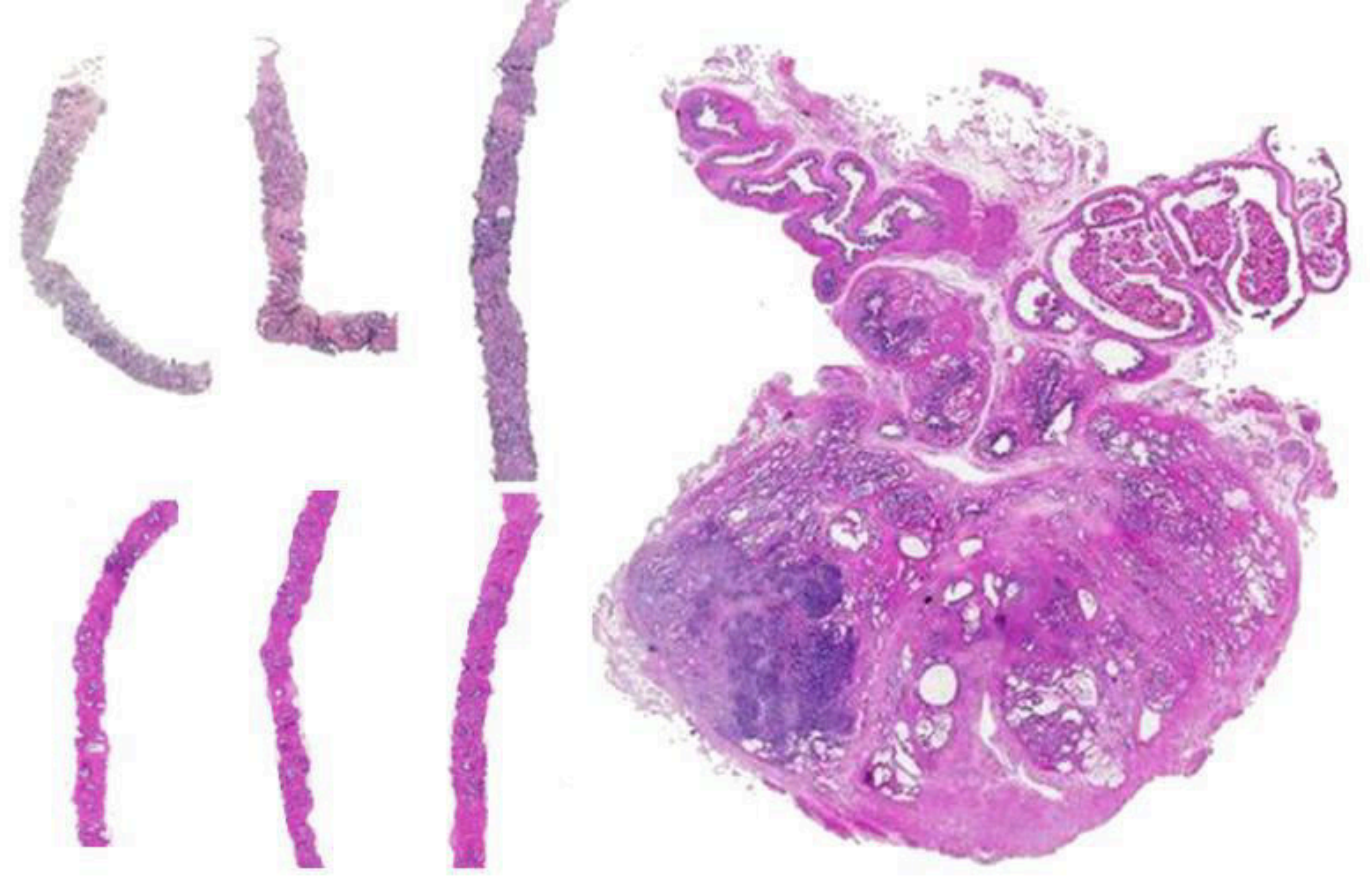

Figure 3. Large-section histology image of a prostate slice with three positive core biopsies (top row) and three negative cores (lower row).

Histological variables obtained from the prostatectomy specimens included histological tumour type (DAP or AAP), Gleason score, size measurement of the excised prostate and of the individual tumour foci, determination of the number of tumour foci, evaluation of the surgical margins, presence of ECE, vascular invasion, seminal vesicle invasion and description of the presence or absence of high-grade prostatic intraepithelial neoplasia (PIN). Ductal differentiation in the tumours was established on the basis of cellular characteristics and histological growth patterns, as described in the literature (40). The ductal parts of the tumour were composed of tall columnar cells (in contrast to cuboidal cells of the acinar cancers). The following growth patterns were regarded as typical of ductal differentiation: papillary, cribriform, and solid. Typical images illustrating the morphological criteria are shown in Figure 4. 

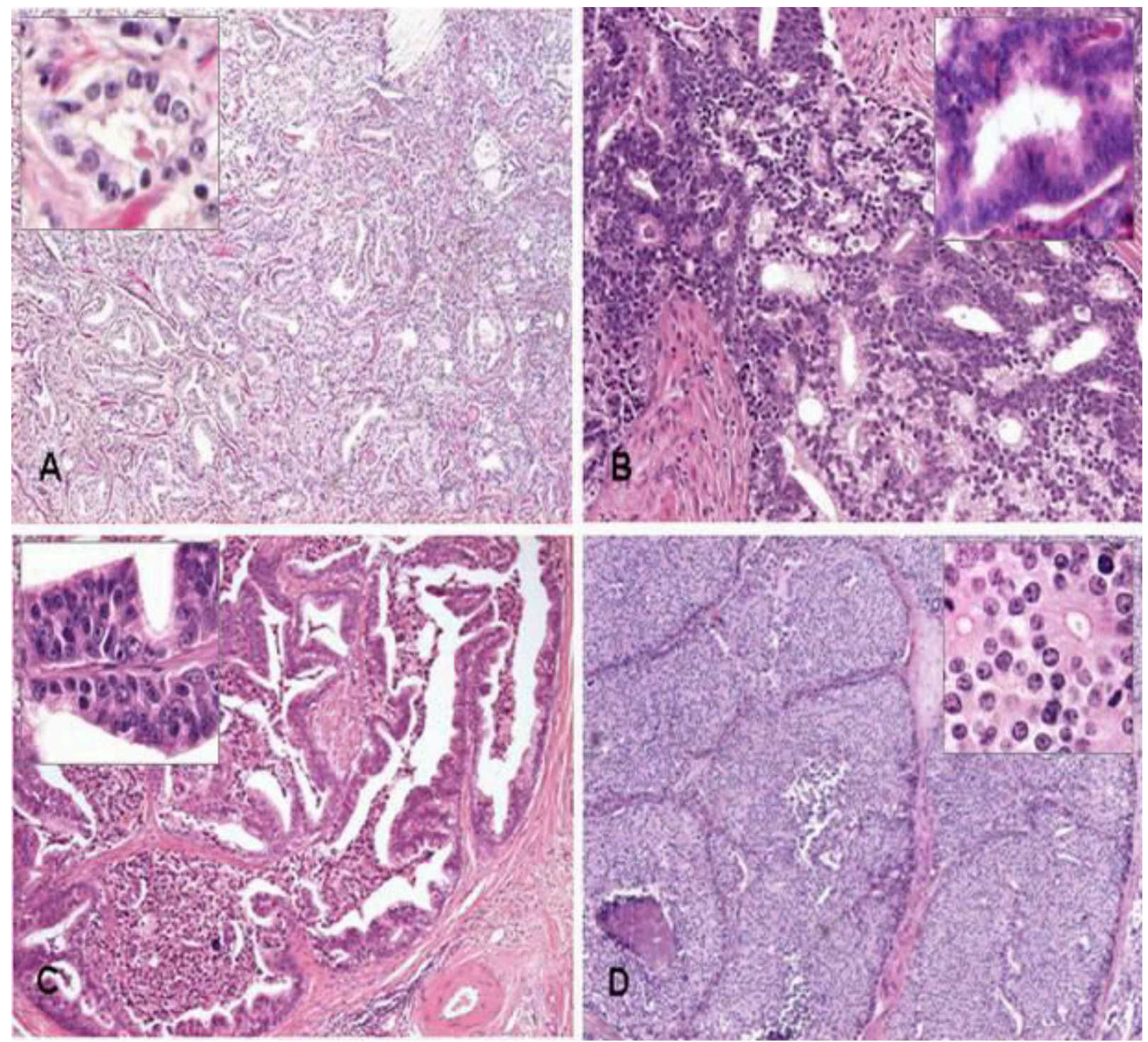

Figure 4. The basic growth patterns in acinar (A) and ductal (cribriform [B], papillary and PIN-like $[C]$, and solid [D]) prostate cancers (H\&E 100X). Inserts with high power magnification details from the same tumours.

Each case was analysed using a subgross, 1,500 micron thick 3D section technique: the paraffin block was melted in an incubator, the specimen was then placed into a series of xylene baths over a $24-\mathrm{hr}$ period in order to complete the deparaffinization. After rehydration the tissue was stained with Harris haematoxylin and immersed in methyl salicylate for clarification. Low-power stereoscopic microscopy (5-10X magnification) was used to view the specimen while immersed in methyl salicylate (37). 
Morphological criteria for evidencing ductal differentiation within a tumour in large format thick (3D) sections were: presence of large contorted cancer-filled ducts found in the periurethral or, unusually, in subcapsular location, associated with or in close proximity to the acinar part of the cancer; or presence of innumerable duct-like structures observed in large areas of the prostate, within the tumour and also in the adipose tissue surrounding the prostate (a rare finding). Typical cases of DAP and AAP are illustrated in Figure 5.

Pure DAP and mixed ductal-acinar carcinomas were grouped together (they appear as DAP through the text). The extent of ductal differentiation within the tumour was not analysed. 

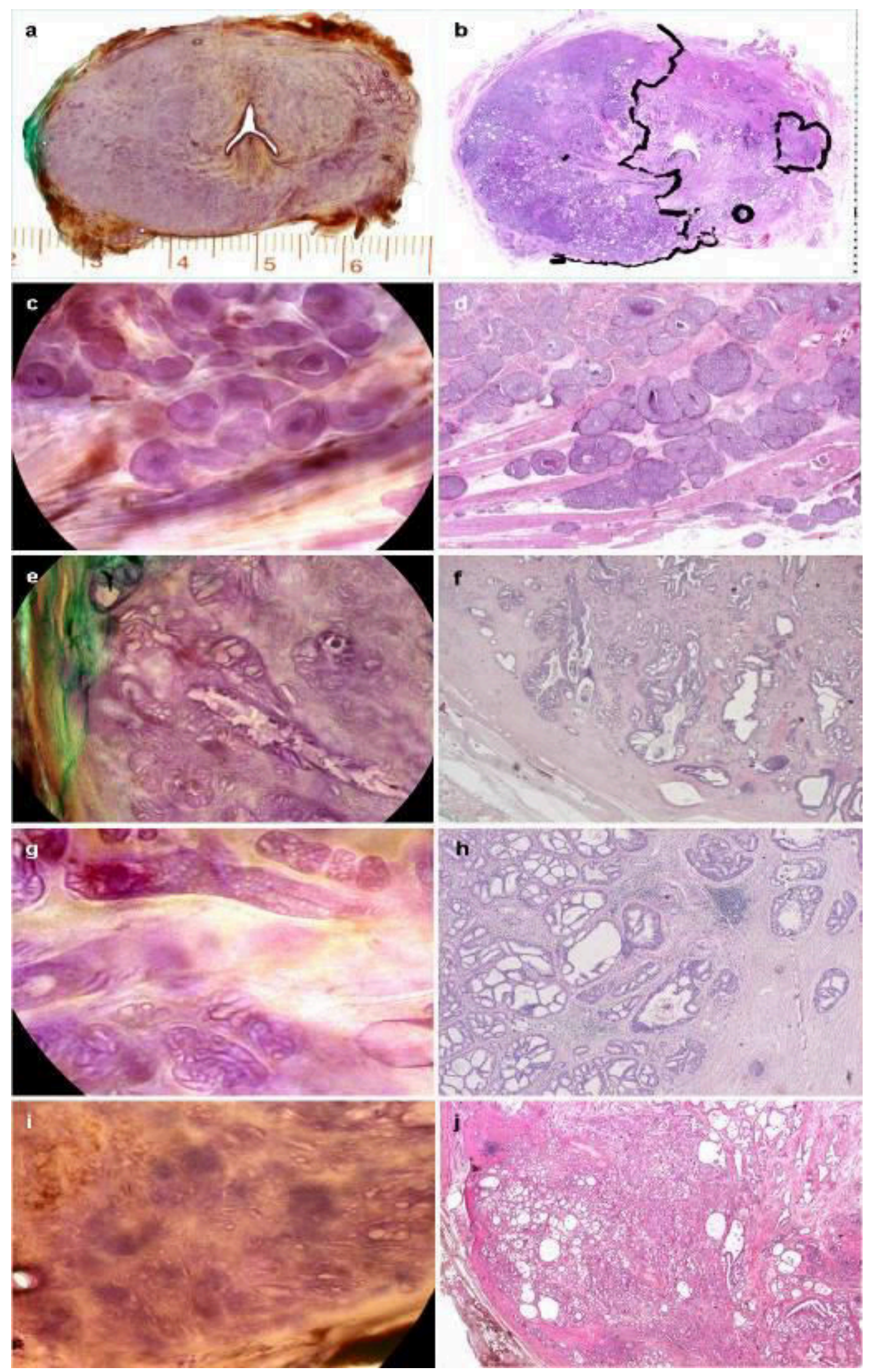

Figure 5. Thick large-format (3D) histology section of a prostatectomy specimen (a); the corresponding two-dimensional (2D) large-format slide (b); comedo growth pattern in DAP in 3D (c) and 2D (d) histology; papillary DAP in 3D (e) and 2D (f) histology; pure cribriform growth pattern in DAP in 3D (g) and 2D (h) histology; AAP for comparison, 3D (i) and 2D (j) histology. 


\subsection{Immunohistochemistry}

Tissue microarray (TMA) blocks were constructed using archival formalin-fixed, paraffinembedded RP specimens from all 110 patients. Two $2 \mathrm{~mm}$ cores were taken from the area of the tumour showing the predominant Gleason pattern of the invasive cancer or from the ductal area, if present. Sections of $3.5 \mu \mathrm{m}$ were cut from the TMA blocks. The TMA slides were immunostained in the Ventana autostainer (Ventana Benchmark XT and Ultra) using Ventana UltraView DAB (760-500). The Ventana stainer uses a multimer cocktail of goat anti-rabbit and goat anti-mouse for the detection system, and horseradish peroxidase conjugate for the visualization of DAB solution. The slides were incubated with diaminobenzidine (DAB) as the chromogene for 10 minutes then counterstained with haematoxylin (Ventana 760-2021) and Bluing Reagent (760-2037) for 4 min. Slides were washed in hot tap water with detergent (YES) then washed in distilled water for $5 \mathrm{~min}$, dehydrated through graded alcohols to xylene baths, and mounted in Pertex organic mounting medium (Histolab, Gothenburg, Sweden). The primary antibodies used are listed in Table 2. 


\begin{tabular}{|c|c|c|c|c|c|c|c|c|}
\hline Antibody & $\begin{array}{l}\text { Major } \\
\text { function }\end{array}$ & $\begin{array}{l}\text { Ref. } \\
\text { number }\end{array}$ & Clone & Species & Dilution & Antigen retrieval & Source & Inst. \\
\hline $\begin{array}{l}\text { Ki-67 } \\
\text { lot:00062416 }\end{array}$ & Proliferation & M7240 & MIB-1 & mouse & $1: 100$ & CC1 mild 30 min & DAKO & $\mathrm{XT}$ \\
\hline $\begin{array}{l}\text { p53 } \\
\text { lot:668526 }\end{array}$ & $\begin{array}{l}\text { Tumour } \\
\text { suppression }\end{array}$ & $800-2912$ & DO-7 & mouse & RTU & CC1 mild $30 \mathrm{~min}$ & Ventana & $\mathrm{XT}$ \\
\hline $\begin{array}{l}\text { p16 } \\
\text { lot:H2109 }\end{array}$ & $\begin{array}{l}\text { Tumour } \\
\text { suppression }\end{array}$ & SC-1207 & - & $\begin{array}{l}\text { rabbit } \\
\text { poly }\end{array}$ & $1: 25$ & CC2 mild 36 min & $\begin{array}{l}\text { Santa } \\
\text { Cruz }\end{array}$ & Ultra \\
\hline $\begin{array}{l}\text { p27 } \\
\text { lot:038(501) }\end{array}$ & $\begin{array}{l}\text { Tumour } \\
\text { suppression }\end{array}$ & M7203 & $\begin{array}{l}\text { SX53G } \\
8\end{array}$ & mouse & $1: 25$ & CC1 mild 30 min & DAKO & $\mathrm{XT}$ \\
\hline $\begin{array}{l}\text { Cox-2 } \\
\text { lot:00034 }\end{array}$ & $\begin{array}{l}\text { Inflammation } \\
\text {, decreased } \\
\text { apoptosis }\end{array}$ & M3617 & $\begin{array}{l}\text { CX- } \\
294\end{array}$ & mouse & $1: 50$ & $\begin{array}{l}\text { CC1 mild } 30 \text { min } \\
\text { +amplifying }\end{array}$ & DAKO & $\mathrm{XT}$ \\
\hline $\begin{array}{l}\text { EGFR } \\
\text { Lot: } 00038049\end{array}$ & Proliferation & M7239 & - & mouse & 1.50 & Protease 1; 8 min & DAKO & XT \\
\hline $\begin{array}{l}\text { Tenascin-C } \\
\text { lot:0129A }\end{array}$ & $\begin{array}{l}\text { Matrix } \\
\text { protein }\end{array}$ & M0636 & $\begin{array}{l}\text { DAKO- } \\
\text { TN2 }\end{array}$ & mouse & $1: 50$ & Protease 1; 8 min & DAKO & $\mathrm{XT}$ \\
\hline $\begin{array}{l}\text { Chromogranine A } \\
\text { lot:00011085 }\end{array}$ & NE marker & M0869 & $\begin{array}{l}\text { DAKO- } \\
\text { A3 }\end{array}$ & mouse & $1: 1500$ & CC1 mild 30 min & DAKO & XT \\
\hline $\begin{array}{l}\text { bcl-2 } \\
\text { lot:29108 }\end{array}$ & $\begin{array}{l}\text { Increased } \\
\text { apoptosis }\end{array}$ & $760-4240$ & 124 & mouse & RTU & $\begin{array}{l}\text { CC2 mild } 36 \text { min } \\
\text { +amplifying }\end{array}$ & Ventana & Ultra \\
\hline
\end{tabular}

Table 2. List of primary antibodies used in the present study and the basic technical parameters.

(Inst.: Instrument; CC1: antigen retrieval solution, type 1; CC2: antigen retrieval solution, type 2; NE: neuroendocrine; RTU: ready to use (prediluted); XT: Ventana Bench Mark XT immunohistochemistry instrument; Ultra: Ventana Bench Mark Ultra immunohistochemistry instrument) 
All biopsies were evaluated with all antibodies. The percentage of tumour cell nuclei stained for Ki-67, p53, p16, p27, and bcl-2 were counted, and a cut-off value of $10 \%$ used to distinguish high- and low-expression cases. Chromogranine A expression was estimated using a semi-quantitative scoring system based on the number of chromogranine A positive cells in a "hot spot" area at $400 \times$ magnification (0, negative; 1, 1-4 positive cells; 2, 5-19 cells; and 3 , staining in $\geq 20$ cells). For Cox-2 the intensity of staining was estimated on a four-grade scale ( 0 , absent; 1 , weak; 2 , moderate; and 3 , strong). The staining intensity of tenascin $\mathrm{C}$ was assessed in both the stromal and periglandular areas (0, negative/normal staining; 1, weak/moderate staining; and 2, strong staining). Membranous immunoreactivity for epidermal growth factor receptor (EGFR) was categorized as undetectable (0), staining in less than $10 \%$ of tumour cells or as faint incomplete membrane staining in more than $10 \%$ of the tumour cells (1), weak to moderate, complete membrane staining in more than $10 \%$ of tumour cells (2), and intense complete membrane staining in more than $10 \%$ of tumour cells (3).

\subsection{Statistical analysis of the biomarker study}

The Chi-square test was used to assess the relationship of each biomarker to AAP and to DAP. The Fisher's exact test was adopted, if the expected number of cases was less than 5 . We also adopted the logistic regression model to estimate the odds ratios for each biomarker indicating DAP or AAP. The biomarkers shown to be significant in univariate analysis were evaluated in multivariate logistic regression in order to select the most significant biomarkers. The receiver-operating characteristic (ROC) curve was used to assess the discriminatory power of the three selected biomarkers (see later). The area under the curve (AUC) and its 95\% confidence interval were calculated according to Hanley (41). We tested the preoperative discriminative ability of three selected biomarkers to predict the risk of DAP among 24 preoperative core biopsy samples from 110 cases and adjusted to the baseline risk of the 24 test cases on eight different combinations of the three biomarkers. The entire material was followed up until August 31, 2010, giving a mean follow-up time of 5.1 years (60.9 months, standard deviation 21.2). 


\subsection{Statistical analysis of the ECE study}

The presence or absence of ECE, defined as penetration of the tumour beyond the capsule of the prostate, was correlated with the number of positive (tumour-containing) needle biopsies (none, one, two or three) using Chi-square test. The data were analysed in two different ways to determine the value of at least sextant needle biopsies in the prediction of ECE. First, a side-for-side analysis was performed in the 168 prostatic sides (84 cases) available in this series. The number of positive needle biopsies on each side (none, one, two or three) was correlated with the presence or absence of ECE at RP. Secondly, for each patient, a dominantside analysis was performed to assess the utility of systematic needle biopsies in predicting ECE in the side containing the greatest tumour volume. In this analysis, the number of positive needle biopsies (one, two or three) in the dominant lobe was correlated with the presence or absence of extracapsular disease. In these cases we calculated the sensitivity, specificity, and the negative and positive predictive values of the number of involved preoperative core biopsies in predicting ECE.

The preoperative PSA levels as well as the biopsy Gleason score was also registered in every case. PSA levels higher than $10 \mathrm{ng} / \mathrm{ml}$ and Gleason score higher or equal to 7 were regarded as high-risk parameters and were also tested as individual parameters and in combination with the number of positive cores.

\subsection{Ethics}

The study was approved by the Regional Ethical Committee of the Uppsala-Örebro Health Care Region, Sweden (Dnr:2010/087). All surviving patients gave written consent for the use of the prostate histology samples for research purposes.

\section{RESULTS}

\subsection{Comparison of DAP with AAP}

The subgross (3D) histology specimens together with routine large format histology slides demonstrated focal ductal differentiation in 12 cancers (mixed ductal-acinar cases) and evidenced one case of pure DAP. The remaining 97 cases were AAPs. Table 3 summarizes 
the clinical and pathological characteristics of cases of pure AAPs $(97 / 110 ; 88 \%)$ and DAPs $(13 / 110 ; 12 \%)$.

\begin{tabular}{|c|c|c|c|}
\hline Parameter & $\begin{array}{c}\text { Acinar } \\
\text { adenocarcinoma } \\
(\mathbf{A A P})\end{array}$ & $\begin{array}{c}\text { Ductal/mixed } \\
\text { ductal-acinar } \\
\text { adenocarcinoma } \\
\text { (DAP) }\end{array}$ & p-value \\
\hline Number of cases & $97 / 110(88 \%)$ & $13 / 110(12 \%)$ & \\
\hline Mean patient age (years) & $61.95(38-78)$ & $63.08(52-69)$ & 0.5793 \\
\hline Positive digital rectal examination & $35 / 97(36 \%)$ & $10 / 13(77 \%)$ & 0.0049 \\
\hline $\begin{array}{l}\text { Size }(\mathrm{mm}) \text { of prostate measured by transrectal } \\
\text { ultrasound }\end{array}$ & $28.4(15-102)$ & $34.6(22-60)$ & 0.0021 \\
\hline Preoperative PSA level, ng/ml & $8.04(2.1-26)$ & $8.97(3.7-19)$ & 0.4869 \\
\hline $\begin{array}{l}\text { Postoperative PSA level } \\
\geq 0.2 \mathrm{ng} / \mathrm{ml}\end{array}$ & $0.49(0.22-1)$ & $0.75(0.20-1.30)$ & 0.4143 \\
\hline Number of pT2 cases & $71 / 97(73 \%)$ & $2 / 13(15 \%)$ & $<0.0001^{*}$ \\
\hline Number of pT3a and pT3b cases & $23 / 97(24 \%)$ & $8 / 13(61 \%)$ & \\
\hline Number of pT3c cases & $3 / 97(3 \%)$ & $2 / 13(15 \%)$ & \\
\hline Number of pT4a cases & $0 / 97$ & $1 / 13(8 \%)$ & \\
\hline Cases with a single tumour focus & $5 / 97(5 \%)$ & $1 / 13(8 \%)$ & $0.3459^{*}$ \\
\hline Cases with 2-4 tumour foci & $69 / 97(71 \%)$ & $7 / 13(54 \%)$ & \\
\hline Cases with $>5$ tumour foci & $23 / 97(24 \%)$ & $5 / 13(38 \%)$ & \\
\hline Cases with the largest tumour focus $1-19 \mathrm{~mm}$ & $55 / 97(56 \%)$ & $3 / 13(23 \%)$ & $0.0020^{*}$ \\
\hline Cases with the largest tumour focus $20-39 \mathrm{~mm}$ & $42 / 97(43 \%)$ & $8 / 13(62 \%)$ & \\
\hline Cases with the largest tumour focus $\geq 40 \mathrm{~mm}$ & $0 / 97$ & $2 / 13(15 \%)$ & \\
\hline Disease extent, $\mathrm{mm}$ & $36.49(10-53)$ & $41.54(21-70)$ & 0.0605 \\
\hline Presence of high grade PIN & $52 / 97(54 \%)$ & $12 / 13(92 \%)$ & 0.0079 \\
\hline Cases with Gleason score $<6$ & $13 / 97(14 \%)$ & $0 / 13$ & $<0.0001 *$ \\
\hline Cases with Gleason score $=6$ & $42 / 97(43 \%)$ & $0 / 13$ & \\
\hline Cases with Gleason score $=7$ & $35 / 97(36 \%)$ & $8 / 13(62 \%)$ & \\
\hline Cases with Gleason score $>7$ & $7 / 97(7 \%)$ & $5 / 13(38 \%)$ & \\
\hline Cases with a positive surgical margin & $16 / 97(16 \%)$ & $6 / 13(46 \%)$ & $0.0219 *$ \\
\hline Cases with extracapsular extension & $25 / 97(26 \%)$ & $11 / 13(84 \%)$ & $<0.0001^{*}$ \\
\hline Cases with vascular invasion & $6 / 97(6 \%)$ & $5 / 13(38 \%)$ & $0.0033^{*}$ \\
\hline Cases with seminal vesicle infiltration & $3 / 97(3 \%)$ & $3 / 13(23 \%)$ & $0.0213^{*}$ \\
\hline Cases with biochemical/local recurrence & $11 / 97(11 \%)$ & $8 / 13(62 \%)$ & $<0.0001^{*}$ \\
\hline Cases with locoregional lymph node metastases & 0/97 & $2 / 13(15 \%)$ & \\
\hline Cases with distant metastases & $0 / 97$ & $3 / 13(23 \%)$ & \\
\hline Cases with prostate cancer death & $0 / 97$ & $1 / 13(8 \%)$ & $0.1508 *$ \\
\hline Cases with death from other disease & $3 / 97(3 \%)$ & $0 / 13$ & \\
\hline Cases with adjuvant radiotherapy & $14 / 97(14 \%)$ & $6 / 13(46 \%)$ & $0.0020^{*}$ \\
\hline Cases with adjuvant hormonal therapy & $4 / 97(4 \%)$ & $4 / 13(31 \%)$ & $0.0109^{*}$ \\
\hline Cases with adjuvant total androgen blockage & $0 / 97$ & $3 / 13(23 \%)$ & $0.0013^{*}$ \\
\hline Cases with adjuvant chemotherapy & $0 / 97$ & $1 / 13(8 \%)$ & $0.1182 *$ \\
\hline
\end{tabular}

Table 3. The clinical and pathological characteristics of the prostate cancer patients according to the presence or absence of a ductal component. Data are shown as $\mathrm{n} / \mathrm{N}(\%)$ or mean (range). * Fisher exact test 
The DAP cases had a significantly greater frequency of the following parameters: positive digital rectal examination $(\mathrm{p}=0.0049)$, mean prostate size measured by transrectal ultrasound $(\mathrm{p}=0.0021), \mathrm{pT} 3 \mathrm{a}$ and more advanced cancers $(\mathrm{p}<0.0001)$, largest tumour focus $>20 \mathrm{~mm}$ $(\mathrm{p}=0.0020)$, high grade PIN $(\mathrm{p}=0.0079)$, Gleason score $\geq 7 \quad(\mathrm{p}<0.0001)$, positive surgical margin $(p=0.0219)$, ECE $(p<0.0001)$, vascular invasion $(p=0.0033)$, seminal vesicle infiltration $(\mathrm{p}=0.0213)$, biochemical/local recurrence, regional lymph node metastases, distant metastases $(\mathrm{p}<0.0001)$. The AAP cases had a significantly greater frequency of the following parameters: case frequency, pT1 and pT2 cases $(\mathrm{p}<0.0001)$, largest tumour focus $<20 \mathrm{~mm}$ $(\mathrm{p}=0.0020)$ and Gleason score $\leq 6(\mathrm{p}<0.0001)$. There was no statistically significant difference in the patients' age at the time of prostatectomy, preoperative and postoperative PSA levels, and number of tumour foci or disease extent.

Although all of the cases were clinically organ-confined at the time of RP, histologic examination confirmed that only $15 \%(2 / 13)$ of the DAP cases and $73 \%$ (71/97) of the AAP cases were organ confined. Of the 21/110 patients who were selected for bilateral pelvic lymphadenectomy, metastases were found in two, both of which were DAP cases.

The outcome measures were all consistently poorer for DAP. During the average follow-up time of 5.1 years (range 4-10 years) all 13 DAP cases had evidence of disease progression: biochemical or local recurrence in 8 cases, distant metastases in 3 cases (one of whom died of the disease), lymph node metastases in 2 cases. In contrast, there was no evidence of disease progression in 86 (89\%) of the 97 AAP cases. Disease progression was limited to biochemical recurrence only in the remaining $11(11 \%)$ of these 97 cases, all 11 of which had a considerable tumour burden, with the largest tumour focus measuring at least $25 \mathrm{~mm}$ or being extensively multifocal. Among the 97 AAP cases, three patients died of unrelated causes during the follow-up period.

\subsection{Analysis of potential biomarkers of poor prognosis}

Table 4 shows the unadjusted and adjusted odds ratios for the ability of biomarkers to discriminate PC of acinar versus ductal origin in the total prostatectomy specimens. 


\begin{tabular}{|c|c|c|c|c|c|c|}
\hline Biomarkers & $\begin{array}{l}\text { AAP } \\
\text { No.(\%) }\end{array}$ & $\begin{array}{c}\text { DAP } \\
\text { No.(\%) }\end{array}$ & $\begin{array}{l}\text { Unadjusted } \\
\text { Odds Ratio }\end{array}$ & $\begin{array}{c}\text { Univariate } \\
95 \% \mathrm{Cl}\end{array}$ & $\begin{array}{l}\text { Adjusted } \\
\text { Odds } \\
\text { Ratio }\end{array}$ & $\begin{array}{c}\text { Multivariate } \\
95 \% \mathrm{Cl}\end{array}$ \\
\hline \multicolumn{7}{|l|}{ Ki67 } \\
\hline $1-9 \%$ & $71(94.7)$ & $4(5.4)$ & 1 & & & \\
\hline$\geq 10 \%$ & 25 (73.5) & $9(26.5)$ & 6.39 & $(1.81-22.59)^{\star}$ & & \\
\hline \multicolumn{7}{|l|}{ Chromogranine A } \\
\hline Neg or $<4$ cells & $78(95.1)$ & $4(4.9)$ & 1 & & 1 & \\
\hline$\geq 5$ cells & $18(66.7)$ & $9(33.3)$ & 9.75 & $(2.7-35.22)$ * & 11.56 & $(2.04-65.31)$ \\
\hline \multicolumn{7}{|l|}{ Tenascin stroma } \\
\hline Normal/weak & $91(90.1)$ & $10(9.9)$ & 1 & & & \\
\hline Moderate/strong & $5(62.5)$ & $3(37.5)$ & 5.46 & $(1.13-26.33)^{*}$ & & \\
\hline \multicolumn{7}{|l|}{$\begin{array}{l}\text { Tenascin } \\
\text { Periglandular }\end{array}$} \\
\hline Normal & $24(100)$ & $0(0)$ & 1 & & & \\
\hline Weak/moderate/strong & $72(84.7)$ & $13(15.3)$ & $4.35^{+}$ & $(1.05-17.02)^{+}$ & & \\
\hline \multicolumn{7}{|l|}{ EGFR } \\
\hline $\begin{array}{l}10 \% \text { membrane } \\
\text { staining } \\
\text { >=10\%incomplete } \\
\text { membrane staining }\end{array}$ & $92(92.9)$ & $7(7.1)$ & 1 & & 1 & \\
\hline $\begin{array}{l}\geq 10 \% \text { weak, moderate } \\
\text { / strong membrane } \\
\text { staining }\end{array}$ & $5(45.4)$ & $6(54.6)$ & 15.77 & $(3.84-64.84)$ & 11.25 & $(1.71-74.10)$ \\
\hline \multicolumn{7}{|l|}{ p53 } \\
\hline $\mathrm{Neg} / \leq 9 \%$ & $85(96.6)$ & $3(3.4)$ & 1 & & 1 & \\
\hline$\geq 10 \%$ & $12(54.6)$ & $10(45.5)$ & 23.61 & $(5.86-98.15)^{*}$ & 20.83 & $(3.71-116.94)$ \\
\hline \multicolumn{7}{|l|}{ p27 } \\
\hline Neg. or $<=9 \%$ & $68(88.3)$ & $9(11.7)$ & 1 & & & \\
\hline$>=10 \%$ & $28(87.5)$ & $4(12.5)$ & 1.08 & $(0.31-3.8)$ & & \\
\hline \multicolumn{7}{|l|}{ Cox-2 } \\
\hline Neg./Weak & $75(90.4)$ & $8(9.6)$ & 1 & & & \\
\hline Moderate/Strong & $21(80.8)$ & $5(19.3)$ & 2.23 & $(0.66-7.54)$ & & \\
\hline \multicolumn{7}{|l|}{ p16 } \\
\hline $\mathrm{Neg} /<=9 \%$ & $53(93.0)$ & $4(7.0)$ & 1 & & & \\
\hline$>=10 \%$ & $44(83.0)$ & $9(17.0)$ & 2.71 & $(0.78-9.4)$ & & \\
\hline \multicolumn{7}{|l|}{ bcl-2 } \\
\hline $\mathrm{Neg} /<=9 \%$ & $94(89.5)$ & $11(10.5)$ & 1 & & & \\
\hline$>=10 \%$ & $3(60)$ & $2(40)$ & 5.70 & $(0.86-37.9)$ & & \\
\hline
\end{tabular}

Table 4. Unadjusted and adjusted odds ratios of immunohistochemical markers to distinguish pure acinar adenocarcinoma (AAP) of the prostate from ductal/mixed ductal-acinar type adenocarcinoma (DAP) of the prostate on the basis of 110 total prostatectomy specimens. ${ }^{*}$ p value $<0.001 ;{ }^{+}$Exact method 
According to the previously described criteria, 26\% (25/97) of AAP cases expressed Ki67 in 10 percent or more of tumour cell nuclei, 18\% (18/97) were chromogranine A positive, 5\% (5/97) EGFR positive, $12 \%$ (12/97) p53 positive, 5\% (5/97) expressed tenascin C in the tumour stroma, and 74\% (72/97) showed periglandular tenascin $\mathrm{C}$ overexpression. The corresponding numbers for DAP were 69\% (9/13), 69\% (9/13), 46\% (6/13), 77\% (10/13), $23 \%(3 / 13)$, and 100\% (13/13), respectively. No statistically significant differences were seen in $\mathrm{p} 27, \mathrm{cox}-2, \mathrm{p} 16$ and bcl-2 expressions.

At multivariate (adjusted) analysis, three of the biomarkers studied provided the most significant discriminatory power: 12-fold for Chromogranine A (aOR=11.56; 95\% CI:2.0465.38), 11-fold for EGFR (aOR=11.25; 95\% CI:1.71-74.10), 21-fold for p53 percentage $(\mathrm{aOR}=20.83 ; 95 \% \mathrm{CI}: 3.71-116.94)$. Typical reactions in DAP and AAP cases are illustrated in Figure 6. A combination of these three biomarkers made it possible to distinguish between the DAP and AAP cases with an accuracy of 94\% (AUC 0.94; 95\% CI: 0.88-0.99). 


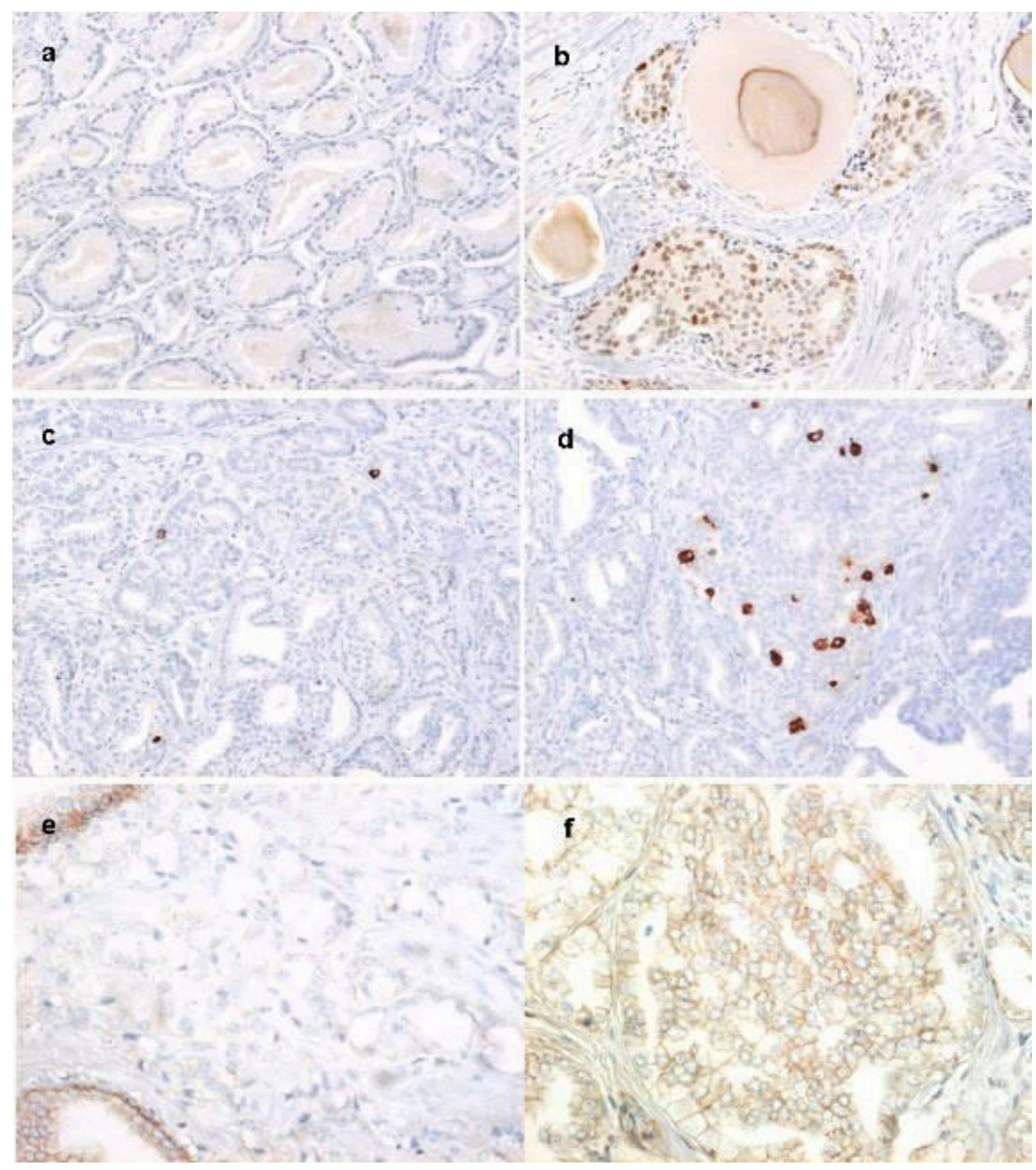

Figure 6. Immunohistochemical p53 expression: absent in AAP (a), present in DAP (b); chromogranine A expression: few positively stained cells in AAP (c), numerous in DAP(d); EGFR expression absent in the AAP, present in the normal glands (e), and present in DAP (f).

Table 5 demonstrates the results of testing the predictive value of the three selected biomarkers (Chromogranine A, EGFR, and p53 percentage) on the preoperative core biopsy tissue samples of 12 known DAP (each contained a characteristic pattern that resembled the ductal component) and 12 known AAP cases. The risk for a case being DAP increased with the number of positive biomarkers, being almost $100 \%$ for patients with three, followed by 
$91 \%$ to $95 \%$ for those with any two, $46 \%$ to $61 \%$ for those with any single biomarker, and $7 \%$ for those with no demonstrable biomarker positivity. We also confirmed that there was no significant difference between the observed and expected number of cases $\left(\chi^{2}=1.70 ; p=0.89\right)$, supporting the high predictive value of the three biomarkers. Receiver operating characteristic (ROC) curve for the discriminatory power of these biomarkers is demonstrated in Figure 7. (AUC 0.94; 95\% CI: 0.88-0.99).

\begin{tabular}{|c|c|c|c|c|}
\hline $\begin{array}{l}\text { Combinations } \\
\text { of biomarkers }\end{array}$ & EGFR $\dagger$ & $\begin{array}{c}\text { Chromogranine } \\
\mathrm{A}^{*}\end{array}$ & P53t & DAP risk \\
\hline 1 & - & - & - & 0.0691 \\
\hline 2 & + & - & - & 0.4553 \\
\hline 3 & - & + & - & 0.4620 \\
\hline 4 & - & - & + & 0.6074 \\
\hline 5 & + & + & - & 0.9062 \\
\hline 6 & + & - & + & 0.9457 \\
\hline 7 & - & + & + & 0.9470 \\
\hline 8 & + & + & + & 0.9951 \\
\hline \multicolumn{5}{|c|}{$\begin{array}{l}* \text { Chromogranine A: - for negative or }<4 \text { cells } ;+ \text { for } \geq 5 \text { cells } \\
\dagger \text { EGFR: - for negative } /<10 \% \text { membrane staining } / \geq 10 \% \text { incomplete membrane } \\
\text { staining; }+ \text { for } \geq 10 \% \text { weak, moderate } / \text { strong membrane staining } \\
\$ \mathrm{p} 53 \text { percentage: }- \text { for negative } / \leq 9 \% ;+ \text { for } \geq 10 \%\end{array}$} \\
\hline
\end{tabular}

Table 5. The predictive value of the three selected biomarkers in 24 preoperative core biopsy cases.

Note: Since these 24 preoperative core biopsy cases may have a different baseline risk compared to the remaining 86 cases, the baseline risk should be adjusted. The risk of DAP was 50\% (12/24) in the preoperative dataset, which was higher than the risk of $11.8 \%(13 / 110)$ in the trained dataset. The adjustment is described as follows. The predictive probability of being DAP in the trained dataset (110 samples) was

$\hat{P}=\frac{\mathrm{e}^{\text {Score }}}{1+\mathrm{e}^{\text {Score }}}$

Score $=-4.8883+2.4476 \times$ Chra $+2.4208 \times E G F R+3.0364 \times p 53$

Given the fact that the frequencies of positive results on Chromogranine A, EGFR, and p53 in the validated dataset are $37.5 \%, 12.5 \%$, and $45.8 \%$, respectively, substituting these figures into the equation with the probability equal to 0.5 yielded the adjusted intercept of -2.6 , which replaces the figure of -4.8883 . 


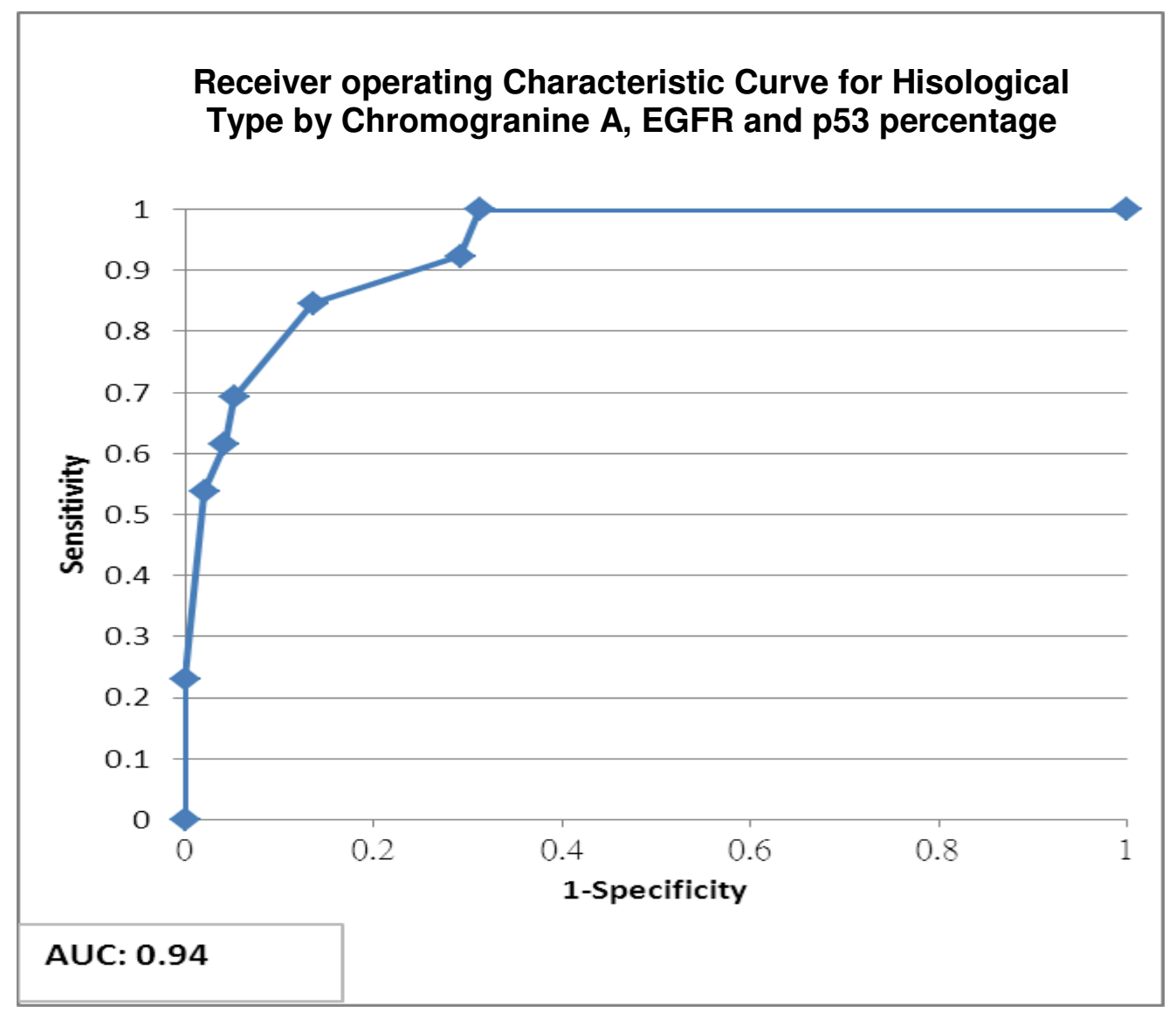

Figure 7. Receiver operating characteristic (ROC) curve for the discriminatory power of the combined biomarkers Chromogranin A, EGFR and p53 percentage

\subsection{Prediction of ECE}

Overall, of the 168 sides analysed, none of the three / four cores contained tumour tissue in 39 cases $(23.2 \%)$, only one of three / four in 67 cases (39.8\%), two of three / four in 39 cases $(23.2 \%)$, and three of three / four biopsies were positive in 23 cases (13.6\%), respectively. Analysis of the 168 prostate sides revealed a significant association between the number of positive needle cores per side and the histopathologic finding of ECE ( $p=0.0003)$. Specifically, when 0 to 1 needle core contained tumour tissue, ECE was detected in only $5.1 \%$ and $13.4 \%$ of prostate sides, respectively. Conversely, when two or three of three / four needle cores were positive ECE was detected in $35.8 \%$ and $65.2 \%$ of sides, respectively (Figure 8). 


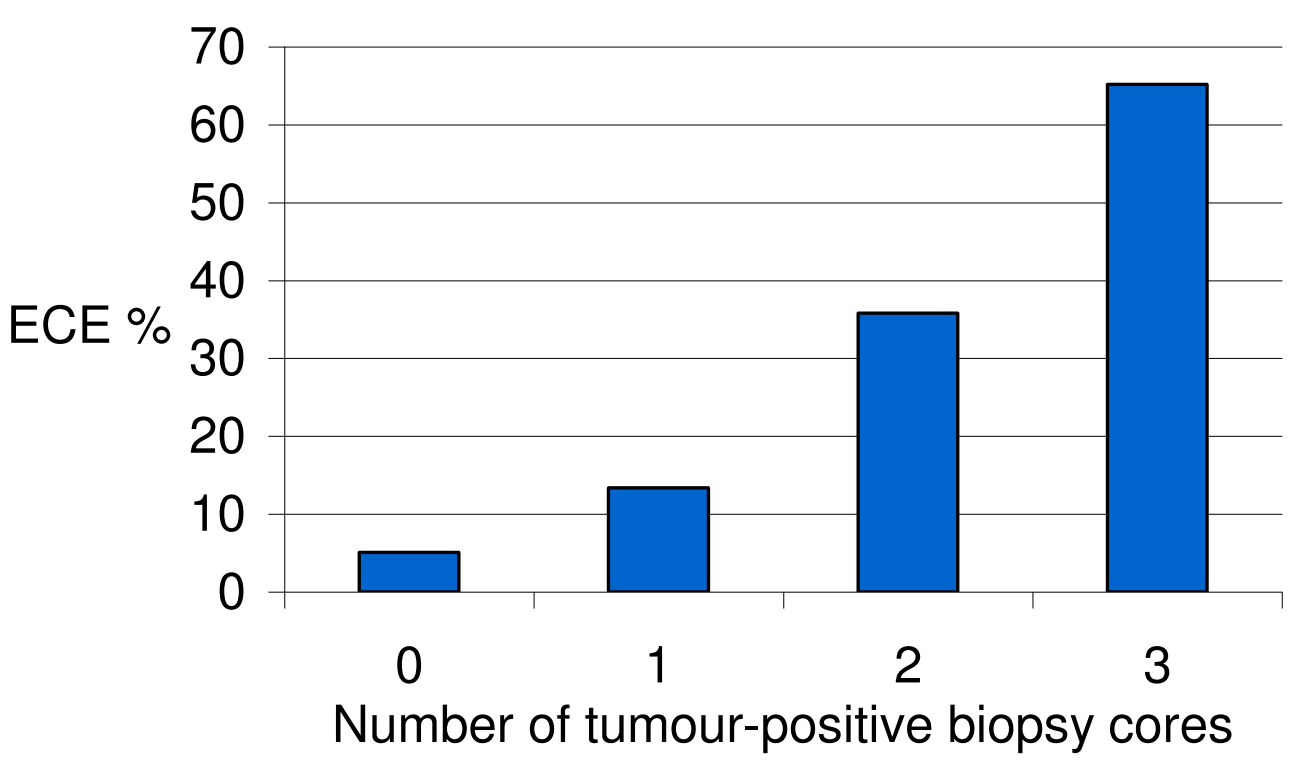

Figure 8. Side-for-side (168 sides) analysis of at least sextant biopsies showing a significant association ( $\mathrm{p}=0.0003)$ between the number of positive biopsy cores per side and the finding of ECE at RP.

A dominant-side analysis of the same subset of patients again demonstrated a significant association between the number of positive sextant or octant biopsy cores and the presence of ECE (Figure 9). ECE was seen in only $5.7 \%$ of the sides that preoperatively had one needle core biopsy specimen positive for tumour. In contrast, ECE was seen in $20.6 \%$ and $60 \%$ of sides that had two or three tumour-positive needle cores preoperatively $(\mathrm{p}=0.008)$. 


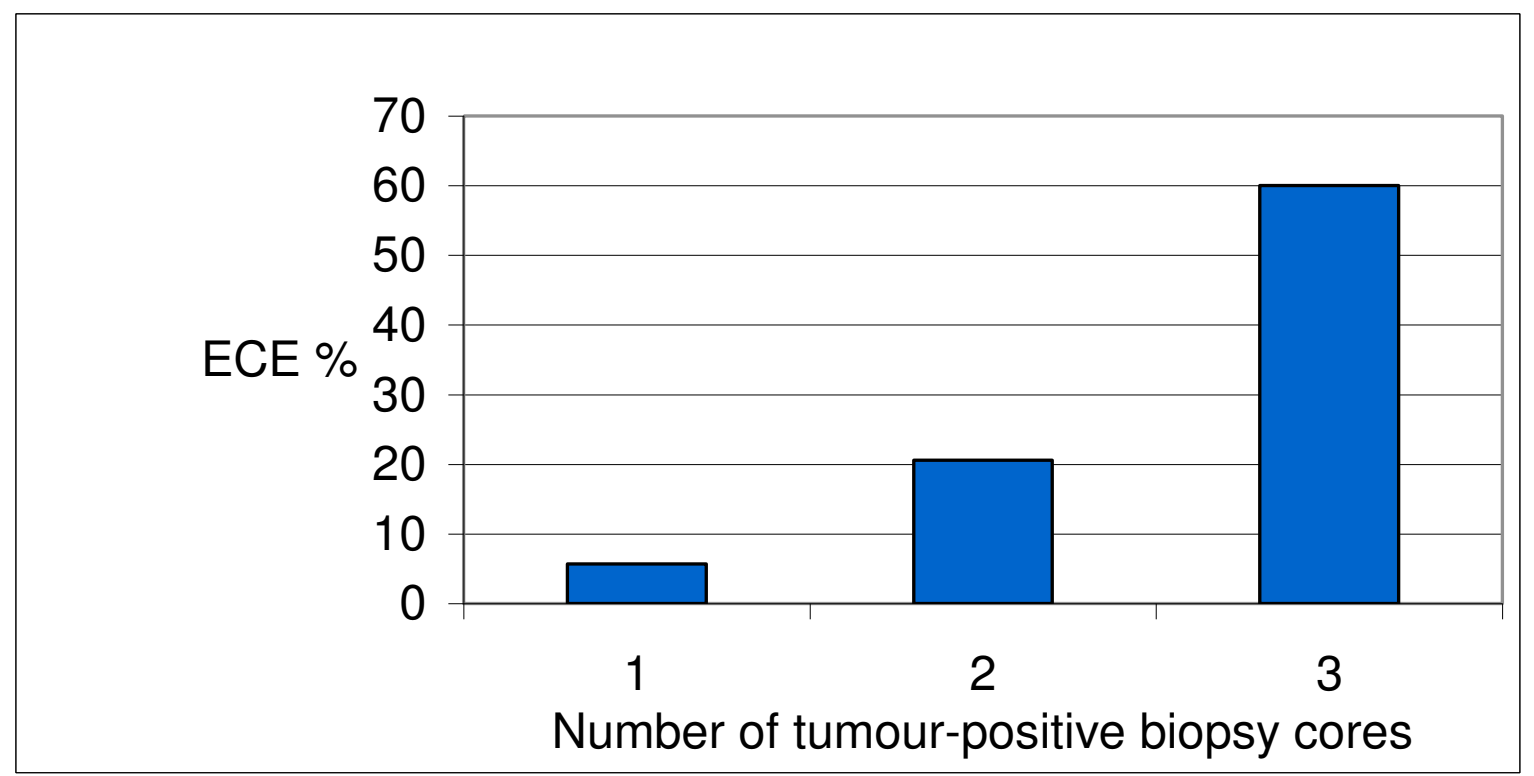

Figure 9. Dominant side ( 84 sides) analysis demonstrating an association $(p=0.008)$ between the number of positive biopsy cores per side and finding of ECE at RP.

To calculate sensitivity, specificity and positive and negative predictive values, it was necessary to define a cut-off value for positive and negative test results for systematic needle biopsy data. As our data indicated that patients with prostate sides containing no or one core positive out of the three or four available were at significantly lower risk of extracapsular disease than those containing two or three positive cores, the finding of no or only one tumour-positive needle cores was defined as a negative test result for ECE. Conversely, as the risk of having ECE in patients with prostate sides giving two or three tumour-positive needle cores was several times higher, this finding was used to indicate a positive test result. Analysis of the 168 prostate sides revealed that systematic needle biopsies had a positive predictive value of $46.7 \%$ and negative predictive value of $89 \%$ (Table 6). 


\begin{tabular}{l|c|c} 
& No ECE & ECE \\
\hline 0-1 positive biopsy cores & 95 & 11 \\
\hline $\mathbf{2 - 3}$ positive biopsy cores & 33 & 29 \\
\hline
\end{tabular}

Specificity: $74 \%$

Sensitivity: $72.5 \%$

Negative Predictive Value: $89 \%$

Positive Predictive Value: $46.7 \%$

Table 6. Results of the side-for-side analysis in predicting ECE

Dominant-side (84 sides) analysis test results are shown in Table 7. In this case the positive and the negative predictive values were $37 \%$ and $94 \%$, respectively.

\begin{tabular}{l|c|c} 
& No ECE & ECE \\
\hline 1 positive biopsy core & 33 & 2 \\
\hline 2-3 positive biopsy cores & 31 & 18 \\
\hline $\begin{array}{l}\text { Specificity: } \mathbf{5 1 \%} \\
\text { Sensitivity: } 90 \%\end{array}$ \\
$\begin{array}{l}\text { Negative Predictive Value: } \mathbf{9 4 \%} \\
\text { Positive Predictive Value: } \mathbf{3 7 \%}\end{array}$
\end{tabular}

Table 7. Results of the dominant side analysis in predicting ECE

Figure 10 illustrates the presence or absence of ECE in relation to PSA levels, while Figure 11 shows its relation to the Gleason score. Presence of ECE in relation to the combination of the three analysed parameters (number of positive biopsy cores, preoperative PSA level and biopsy Gleason score) is presented in Figure 12. 


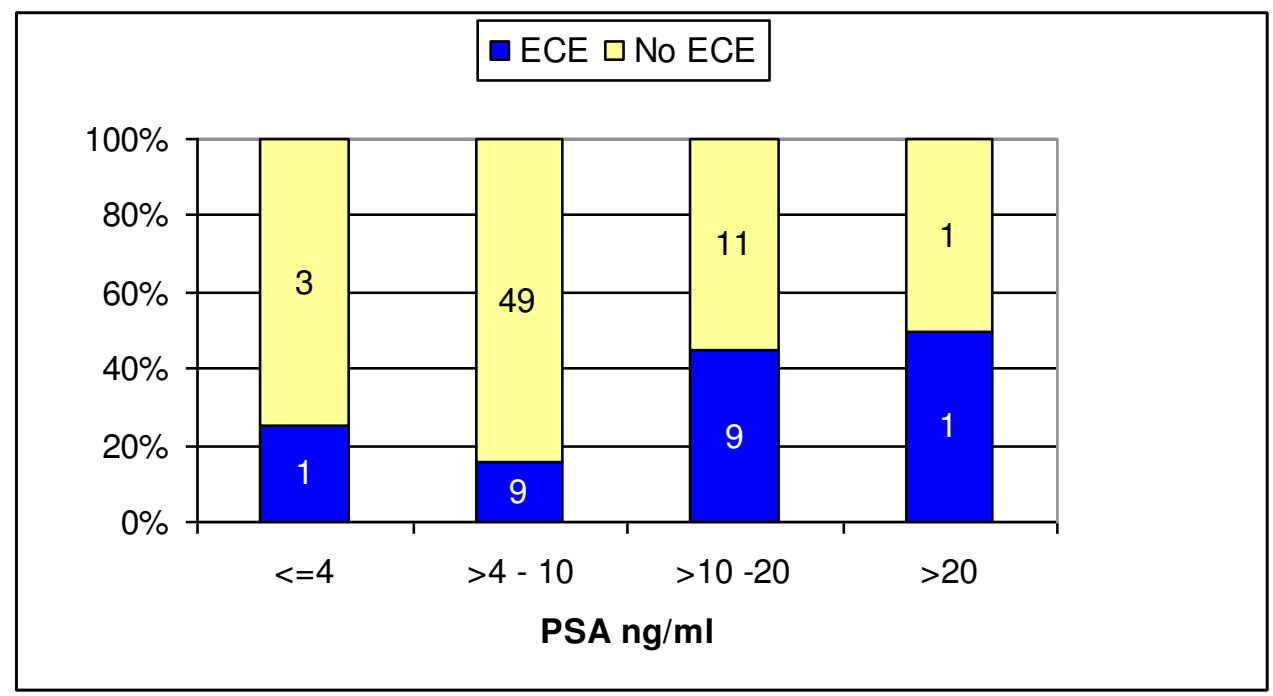

Figure 10. Relationship between the preoperative PSA level and the presence of ECE at RP

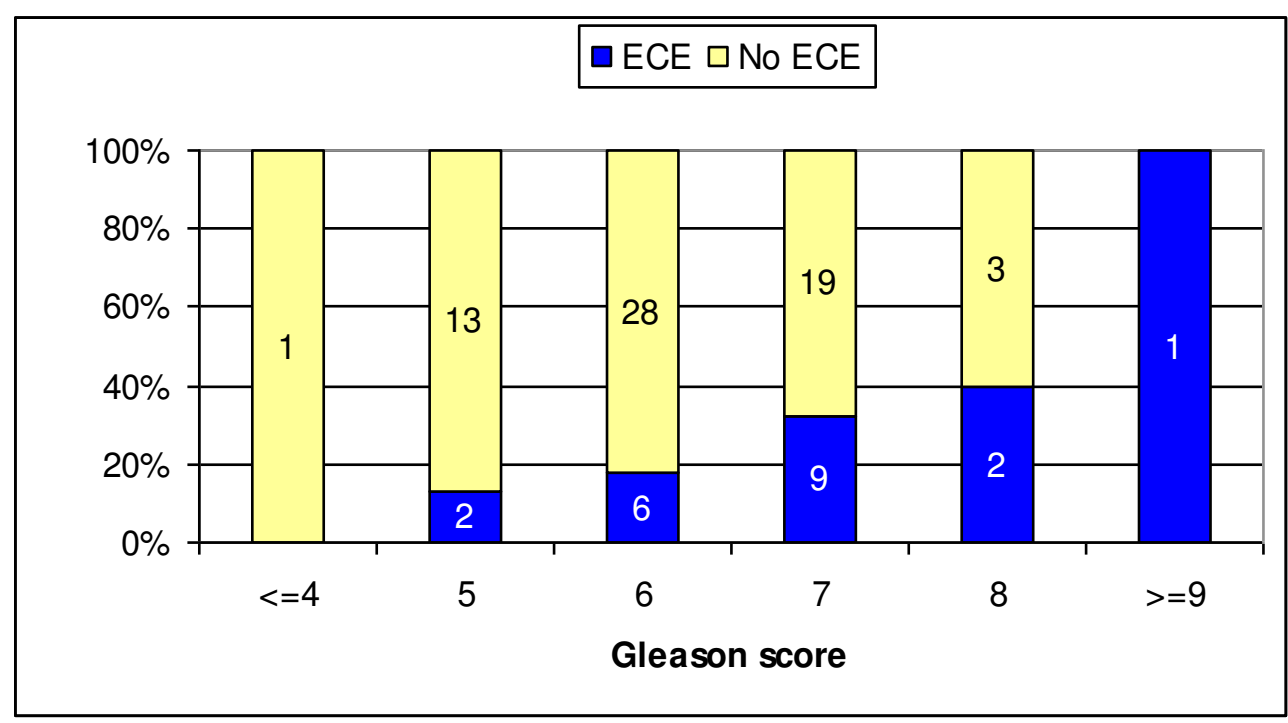

Figure 11. Relationship between the biopsy Gleason score and the presence of ECE at RP 


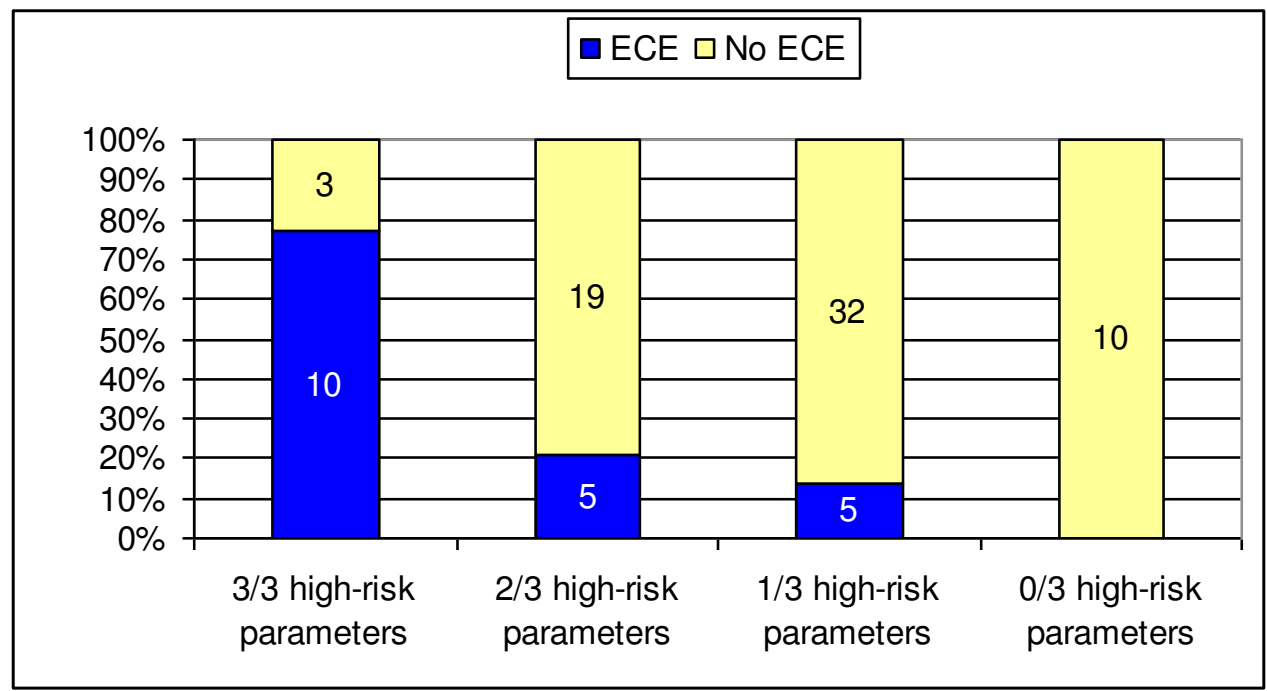

Figure 12. Relationship between the combination of three prognostic parameters (number of positive biopsies, preoperative PSA level and biopsy Gleason score) and the presence of ECE at RP. The highrisk parameters are: number of positive biopsies $>1$; Gleason score 7 or more; serum PSA $>10 \mathrm{ng} / \mathrm{ml}$.

\section{DISCUSSION}

DAP was initially described in 1967 as "endometrial carcinoma" because of its histological resemblance to endometrial carcinoma and presumed origin from the verumontanum, a Mullerian structure (42). The initial impression in the pathology literature was that of a truly endometrial tumour arising in a vestigial Mullerian structure. However, subsequent reports on favourable response to orchiectomy (43) and immunohistochemistry $(21,44,45)$ have proven that it is a neoplasm of prostatic origin. Consequently, the term endometrial adenocarcinoma of the prostate is no longer justified.

The most important original articles on DAP are summarized in Table 8. 


\begin{tabular}{|c|c|c|c|c|c|}
\hline References & Country & $\begin{array}{l}\text { Type of } \\
\text { the study }\end{array}$ & $\begin{array}{l}\text { Study } \\
\text { Period }\end{array}$ & $\begin{array}{l}\text { No. of } \\
\text { DAP }\end{array}$ & Most important message of study \\
\hline $\begin{array}{l}1 . \\
\text { Walker et al, } \\
1982(44)\end{array}$ & USA & $\begin{array}{l}\text { Case } \\
\text { report }\end{array}$ & 1982 & 1 & $\begin{array}{l}\text { The immunohistochemical findings and the close association of the } \\
\text { adenocarcinoma with the prostatic epithelium of the villous polyp provided } \\
\text { evidence that so-called endometrial carcinoma of the prostatic utricle is of } \\
\text { prostatic epithelial origin rather than of Mullerian derivation. }\end{array}$ \\
\hline $\begin{array}{l}2 . \\
\text { Bostwick et } \\
\text { al, } 1985(45)\end{array}$ & USA & Histo. & $\begin{array}{l}1968- \\
1982\end{array}$ & 13 & $\begin{array}{l}\text { They agree with the suggestion of Walker et al (44) that the term } \\
\text { "endometrial" should be abandoned. They prefer to classify these as prostatic } \\
\text { adenocarcinomas with endometrioid features. These tumours are clinically } \\
\text { more aggressive than previously thought. }\end{array}$ \\
\hline $\begin{array}{l}\text { 3. } \\
\text { Epstein et al, } \\
1986(21)\end{array}$ & USA & Histo. & $\begin{array}{l}1963- \\
1983\end{array}$ & 10 & $\begin{array}{l}\text { They supports the concept of Bostwick et al }(45) \text { and Walker et al (44) that } \\
\text { prostatic carcinomas with endometrioid features is a morphologic variant of } \\
\text { DAP. These tumours have not shown Mullerian nature. }\end{array}$ \\
\hline $\begin{array}{l}4 . \\
\text { Christensen } \\
\text { et al 1991(23) }\end{array}$ & USA & Histo. & $\begin{array}{l}1986- \\
1989\end{array}$ & $\begin{array}{l}15 \text { with } \\
\mathrm{RP}\end{array}$ & $\begin{array}{l}\text { DAP-s are in advanced pathologic stage by the time of presentation and have } \\
\text { a much higher short-term failure rate after RP than AAP. }\end{array}$ \\
\hline $\begin{array}{l}\text { Millar et al, } \\
1996(46)\end{array}$ & UK & Histo. & $\begin{array}{l}1979- \\
1996\end{array}$ & 16 & $\begin{array}{l}\text { Patients with DAP had shown good response to hormone therapy and these } \\
\text { tumours had a relatively good prognosis. }\end{array}$ \\
\hline $\begin{array}{l}6 . \\
\text { Oxley et al, } \\
1998(47)\end{array}$ & UK & $\begin{array}{l}\text { Immuno- } \\
\text { histo. }\end{array}$ & $\begin{array}{l}1982- \\
1996\end{array}$ & $\begin{array}{l}12 \\
6 \text { pure } \\
6 \text { mixed }\end{array}$ & $\begin{array}{l}\text { The percentage of tumours expressing p } 53 \text { was similar to the percentage } \\
\text { published for high grade AAP. The results for Ki-67 suggest that DAP have } \\
\text { higher scores than AAP. }\end{array}$ \\
\hline $\begin{array}{l}7 . \\
\text { Bock et al, } \\
1999(25)\end{array}$ & USA & Histo. & $\begin{array}{l}1992- \\
1994\end{array}$ & 17 & $\begin{array}{l}\text { The only specific feature for DAP is its distinctive site of growth. Papillary and } \\
\text { cribriform growth of cancer on needle biopsy should not be considered } \\
\text { diagnostic. They recommended to reject the diagnosis of DAP. }\end{array}$ \\
\hline $\begin{array}{l}8 . \\
\text { Brinker et al, } \\
1999(22)\end{array}$ & USA & Histo. & -1998 & 58 & $\begin{array}{l}\text { They conclude that DAP seen on needle biopsy implies more advanced } \\
\text { cancer with shortened time to progression. }\end{array}$ \\
\hline $\begin{array}{l}9 . \\
\text { Tu et al, } 2002 \\
\text { (48) }\end{array}$ & USA & Clinical & $\begin{array}{l}1977- \\
1997\end{array}$ & 12 & $\begin{array}{l}\text { PCa patients with penile or testicular metastases have unique clinical and } \\
\text { pathological characteristics. Many of these tumours are compatible with a } \\
\text { subtype of DAP. }\end{array}$ \\
\hline $\begin{array}{l}10 . \\
\text { Orihuela et } \\
\text { al, } 2008(49)\end{array}$ & USA & Clinical & $\begin{array}{l}1990- \\
2005\end{array}$ & 17 & $\begin{array}{l}\text { Contemporary management of localized DAP with radiation and endocrine } \\
\text { therapy yields adequate disease free survival. Patients with metastatic DAP } \\
\text { respond well to endocrine treatment. }\end{array}$ \\
\hline $\begin{array}{l}11 . \\
\text { Tavora et al, } \\
2008(50)\end{array}$ & USA & $\begin{array}{l}\text { Clinical/his } \\
\text { to. }\end{array}$ & $\begin{array}{l}1999- \\
2007\end{array}$ & $\begin{array}{l}28 \text { PIN- } \\
\text { like }\end{array}$ & PIN-like DAP behaved similar to Gleason score 6 AAP. \\
\hline $\begin{array}{l}12 . \\
\text { Lotan et al, } \\
2009(51)\end{array}$ & USA & $\begin{array}{l}\text { Mol. } \\
\text { Pathol. }\end{array}$ & $\begin{array}{l}1984- \\
2005\end{array}$ & 38 & $\begin{array}{l}\text { Significantly lower rate of the TMPRSS2-ERG gene fusion in pure DAP } \\
\text { compared to AAP indicating a genetic and biologic difference between the } \\
\text { two tumour types. }\end{array}$ \\
\hline $\begin{array}{l}13 . \\
\text { Tu et al } 2009 \\
\text { (52) }\end{array}$ & USA & $\begin{array}{l}\text { Clinical/his } \\
\text { to. }\end{array}$ & $\begin{array}{l}1985- \\
2006\end{array}$ & $\begin{array}{l}75 \text { with } \\
\mathrm{RP}\end{array}$ & $\begin{array}{l}\text { They evaluated } 50 \text { mixed and } 25 \text { pure DAP. Pure DAP had better prognosis } \\
\text { than mixed type of DAP. }\end{array}$ \\
\hline $\begin{array}{l}14 . \\
\text { Lee et al, } \\
2010(53)\end{array}$ & USA & Histo. & $\begin{array}{l}1987- \\
2009\end{array}$ & 10 & $\begin{array}{l}\text { They reported } 10 \text { unique histological patterns of DAP and showed the } \\
\text { differential diagnostic difficulties of these tumours. }\end{array}$ \\
\hline $\begin{array}{l}15 . \\
\text { Morgan et al, } \\
2010 \text { (54) }\end{array}$ & USA & Clinical & $\begin{array}{l}1996- \\
2006\end{array}$ & $\begin{array}{l}371 \\
(0,1 \%)\end{array}$ & $\begin{array}{l}\text { Patents with DAP diagnosis are more likely to present with advanced stage } \\
\text { cancer. Men with nondistant disease at diagnosis of DAP had } 2.2 \text {-fold } \\
\text { increase in disease specific mortality. }\end{array}$ \\
\hline $\begin{array}{l}16 . \\
\text { Samaratunga } \\
\text { et al, } 2010 \\
(19)\end{array}$ & $\begin{array}{l}\text { Australi } \\
\text { a }\end{array}$ & Histo. & 2004 & $\begin{array}{l}34 \\
(12,7 \%)\end{array}$ & $\begin{array}{l}\text { Twenty-five cases }(73 \%) \text { with DAP had ECE compared to } 32.9 \% \text { of AAP } \\
\text { cases. They recommended that any portion of ductal component should be } \\
\text { reported in core biopsies specimens. }\end{array}$ \\
\hline
\end{tabular}




\begin{tabular}{|c|c|c|c|c|c|}
\hline $\begin{array}{l}17 . \\
\text { Amin et al, } \\
2011(20)\end{array}$ & USA & Histo. & $\begin{array}{l}1995- \\
2008\end{array}$ & $\begin{array}{l}93 \\
(0,5 \%)\end{array}$ & $\begin{array}{l}\text { DAP admixed with Gleason grade } 3 \text { is more aggressive than Gleason score } 7 \\
\text { AAP, as long as the ductal component is }=10 \% \text {. Gleason score } 8-10 \\
\text { tumours with ductal features are not significantly more aggressive than AAP } \\
\text { Gleason score } 8-10 \text { cancers. }\end{array}$ \\
\hline $\begin{array}{l}18 . \\
\text { Finamanti et } \\
\text { al, } 2011(55)\end{array}$ & Italy & Clinical & $\begin{array}{l}1997- \\
2010\end{array}$ & $\begin{array}{l}56 \\
(4,5 \%)\end{array}$ & $\begin{array}{l}\text { DAP is more likely to present with advanced clinical stage at diagnosis than } \\
\text { AAP }\end{array}$ \\
\hline $\begin{array}{l}19 . \\
\text { Meek et al, } \\
2011(56)\end{array}$ & USA & Clinical & $\begin{array}{l}1970- \\
2011\end{array}$ & $\begin{array}{l}693 \\
(\sim 0,1 \%)\end{array}$ & $\begin{array}{l}\text { DAP is associated with a high rate of } \mathrm{PCa} \text { specific mortality, similar to } \\
\text { Gleason } 4+4 \text { AAP. }\end{array}$ \\
\hline $\begin{array}{l}20 . \\
\text { Our study } \\
2012\end{array}$ & Sweden & $\begin{array}{l}\text { Immuno- } \\
\text { histo. }\end{array}$ & $\begin{array}{l}2000- \\
2006\end{array}$ & $\begin{array}{l}13 \\
(11,8 \%)\end{array}$ & $\begin{array}{l}\text { Assessment of chromogranine A, p53, and EGFR in prostate carcinoma may } \\
\text { serve as useful adjunctive diagnostic tools for delineating more aggressive } \\
\text { prostate cancer cases exhibiting ductal differentiation. }\end{array}$ \\
\hline
\end{tabular}

Table 8. Survey of DAP related literature from PubMed including papers published between 1982 2011.

DAP, as we have defined it, comprised $11.8 \%$ of all tumours in our study, which was based on an unselected consecutive series of 110 patients who underwent RP. This proportion is somewhat higher than the proportion of DAP reported in most previous studies $(23,45,46,53,54)$ although a higher percentage has also been reported (19). We attribute the higher frequency of DAP in our material to the use of subgross (3D) histology in all 110 total prostatectomy samples, because this technique provides better visualization of ductal structures, particularly at the periphery of the prostate, where 12/13 of the DAP tumours were found in our material.

There are many differential diagnostic difficulties when diagnosing DAP on needle biopsies. The most difficult distinction is between cribriform high-grade PIN and DAP. There are several features that may distinguish these two lesions on needle biopsy. DAP often contain true papillary fronds with well-established fibrovascular cores, whereas PIN more frequently shows micropapillary fronds with tall columns of epithelium without fibrovascular stalks. DAP may show stromal fibrosis, haemosiderin deposition or perineural invasion, which would not be seen with PIN. Finally, DAP may consist of very large or back-to-back glands, whereas glands involved by PIN are of the size and distribution of benign glands. We agree with the suggestion of Brinker et al that many of the cases that have been designated as intaductal carcinomas earlier would be now regarded as DAP. Pathologist must be able to 
recognize this morphology as being malignant on needle biopsy regardless of the presence of basal cells (22).

Several recent publications indicated a more aggressive clinical course in cases with DAP compared to AAP, in contrast to occasional reports showing no difference between the two (46). A poor 5-year-survival rate, ranging from $15 \%$ to $43 \%$ was reported by Bostwick et al (45), Christensen et al. (23), Morgan et al. (54) and Samaratunga et al. (19). In the present study, factors that are related to poor prognosis, i.e. tumour stage, high grade PIN, Gleason score, positive surgical margins, ECE, vascular invasion and seminal vesicle infiltration were associated with tumours showing ductal differentiation. As much as $25 \%$ to $40 \%$ of patients with DAP have metastases at the time of diagnosis (52). In addition, these tumours tend to spread to unusual sites, such as the penis, testis, visceral organs (liver, lungs, brain) and skin $(48,57,58)$. Our results also indicate an unfavourable prognosis in cases showing ductal differentiation; visceral metastasis ( 1 case), skeletal metastases (2 cases), locoregional lymph node metastases ( 2 cases), and prostate cancer related death (1 case) were seen exclusively in tumours with ductal differentiation in this study. While some authors indicate that ductal differentiation in less than $10 \%$ of the tumour has no prognostic relevance (20), others, similarly to our study, provided evidence to the contrary (19).

Although there are sporadic reports on DAP exhibiting bcl-2 (59) or CK20 (26) in contrast to AAP, we did not find any systematic studies in the literature regarding specific immunohistological marker panel(s) that would reliably distinguish between DAP and AAP. Therefore, we designed the present study to test commercially available, routinely used antibodies in this setting. We found p53, chromogranine A, EGFR and Ki-67 expression of the tumour cells to be associated with ductal differentiation, and therefore as promising potential immunohistochemical markers of this phenotype.

The prostate gland has the largest population of neuroendocrine cells in the male genital tract. Some authors found a correlation between NED in PCa and Gleason score and/or other factors indicating aggressive behaviour (60).

An increased number of neuroendocrine cells have been reported in advanced tumour stages, high-grade versus low-grade tumours, and especially after patients were treated with androgen suppression (29-31). In contrast, other researchers found no correlation (61). In theory, tumours derived from a more mature progenitor cell in the stem-cell hierarchy tend to be 
homogeneous and express a monoclonal phenotype, whereas tumours derived from an earlier (more pluripotent) progenitor cell tend to be heterogeneous and exhibit a more mixed phenotype (62). This may explain the presence of NED in some less differentiated PCa, and the association of this differentiation with DAP.

The p53 protein induces cell-cycle arrest at the G1 and G2 checkpoints prior to DNA replication and allows the repair of damaged DNA, but also allows the induction of apoptosis. Mutations in the TP53 gene, resulting in loss of the tumour-suppressing functions of wild type (normal) p53 and gain of oncogenic functions are frequently found in invasive cancers, including PCa. Mutations in the TP53 gene are considered a late event in prostate carcinogenesis, and it is unclear whether wild type p53 is expressed in significant amounts in early-stage cancer. Nuclear positivity for p53 in PCa is associated with higher grade tumours, advanced tumour stages, and predicts a poor prognosis (63), an association which was also found in the present study.

EGFR is a membrane-associated tyrosine kinase, and its activity is regulated by ligandbinding and by interactions with receptors of the EGFR family (64). Once this molecule is phosphorylated, the activated signal is passed down through signaling cascades, activating numerous downstream molecules, what ultimately affects cell division, proliferation and cell migration (64). Abnormal signaling in EGFR-related pathways leads to uncontrolled cell growth and has been reported in many solid tumours such as breast, colorectal, head and neck and pancreatic cancers (64).

The molecular mechanisms responsible for PCa development, progression and hormoneindependence are not clear yet. Several findings suggest that alterations of different pathways involving growth factor receptors play a role in this multistep process (65). In particular, EGFR is frequently overexpressed in PCa and this is associated with a more aggressive clinical outcome. EGFR is down regulated at the transcriptional level by androgens in normal prostate tissue but up regulated in prostate malignancy, especially in androgen-independent PCa. EGFR overexpression has also been linked to the transition from androgenresponsiveness to the androgen-independent/hormone-refractory phenotype (66). Di Lorenzo et al. have evaluated by immunohistochemistry the expression of EGFR in three different groups of PCa patients representative of different clinical stages of PCa. EGFR was evaluated as potential prognostic indicator of disease progression. A significant increase in EGFR expression was observed from patients treated with radical surgery alone and not yet exposed 
to hormonotherapy $(41.4 \%)$, to patients who received hormonotherapy as primary therapy before radical prostatectomy (75.9\%), and finally to patients with metastatic and hormonerefractory disease (100\%) (67). Weber et al. have observed a significant association between EGFR expression and higher Gleason scores and poor outcome (68). It remains to be demonstrated if EGFR therapeutic targeting may optimize patient outcome (69).

$\mathrm{Ki}-67$ is a nonhistone protein that identifies proliferating cells. Ki-67 expression has been considered accurate in fresh-frozen tissue. MIB-1 antibody reacts with parts of the Ki-67 antigen and is expressed in paraffin-embedded specimens. MIB-1 expression is similar to that of Ki-67 and is therefore recommended in paraffin-embedded specimens. Some recent studies of patients treated with RP have revealed a positive correlation between Ki-67 expression and cancer recurrence (70).

The prognostic value of MIB-1 staining on paraffin embedded tissue after radical prostatectomy is, however, still controversial. While some authors have reported a correlation with poor prognosis (71-73), others did not $(74,75)$, but it seems that MIB-1 expression is an independent marker of poor prognosis in the majority of the studies. Interestingly, expression of Ki-67 was less significantly different in the DAP and AAP in our study and therefore it was not within the first three selected biomarkers.

A thorough statistical analysis demonstrated that a combination of chromogranine A, p53 and EGFR expression were reliable predictors of the presence of the ductal/mixed ductal-acinar type PCa in our series of prostatectomy specimens and remained reliable in the preoperative core biopsy series. Although these results are sound, larger studies are needed to confirm the discriminatory power of these biomarkers.

Accurate preoperative prediction of the status of surgical margins is of paramount clinical importance for treatment planning, especially for patients being considered for nerve-sparing procedures and/or preoperative neoadjuvant therapy. Paulson et al $(76,77)$ reported that positive margins were associated with decreased cancer specific and overall survival. The cumulative data suggest that surgical margin status is an important predictor of outcome, which in turn means that the ability for preoperative prediction of ECE has important clinical implications. 
To our knowledge, Gancarczky et al`s study (17) represents the largest series of data demonstrating that the percentage of biopsy cores containing carcinoma (number of positive cores per total number of cores taken) is a highly significant independent predictor of ECE at the time of RP. In this study of 1510 patients from the Center for Prostate Disease Research database using univariate and multivariate analyses, pre-treatment PSA, biopsy Gleason score and the percentage of positive biopsy cores were the three most significant pre-treatment parameters predicting the margin status at radical prostatectomy, similar to other previous reports $(15,16,78-82)$.

Tigrani at al (83) studied 108 patients who underwent prostatectomy for PCa and found that the number of positive biopsies was the best predictor of margin status. It is not surprising, as it is known that serum PSA can be higher in simple hyperplasia of the prostate than in cases of malignancy. Serum PSA level is more important for diagnosing PCa and for the follow-up of the patients than for predicting the surgical margin status. However, in our study there was certain association between increased preoperative PSA levels and the presence of ECE at radical prostatectomy (see below).

On the other hand, the discordance between the biopsy Gleason score and final Gleason score is well documented (84). Our study also revealed that this discrepancy can be diminished by increasing the number of preoperative biopsies. In cases of sextant biopsies the association with final pathological Gleason score was only $57.6 \%$, while it reached $79.2 \%$ in octant biopsies.

Our study showed that transrectal ultrasound-guided systematic at least sextant biopsies can be useful in stratifying patients according to the preoperative risk of ECE. In our study population, the prostate sides that demonstrated two or three positive needle biopsies were at several times higher risk of having ECE than those with no or only one positive core.

Our results calculated for systematic sextant needle biopsies and demonstrated in Table 6 and 7, indicate that this test has serious limitations when predicting ECE. Using the finding of two or three tumour-positive biopsy cores out of three (or four) cores taken per side as indicative of extracapsular disease shows a disappointingly low positive predictive value of only $37 \%$ and $46.7 \%$, respectively. However, finding no or only one core sample to be positive for tumour accurately predicted the absence of extracapsular disease with a negative predictive value approaching $89 \%$ and $94 \%$, respectively.

Recently, wide consensus has been reached upon the role of well-determined Gleason score being a powerful prognostic factor for predicting pathologic stage, biochemical failure, local recurrences and lymph node or distant metastases at RP $(14,17,85)$. It also correlates with 
virtually all other adverse pathologic parameters, including tumour volume and inked margin status in radical prostatectomy specimens, serum PSA levels and many molecular markers. Specifically, high Gleason scores (7 or more) are associated with worse prognosis, and Gleason scores 5-6 are usually associated with lower progression rates after definitive therapy (85). In our study, positive association between biopsy Gleason score and the presence of ECE at RP could be demonstrated.

The predictive value of the Gleason score is enhanced when combined with other clinical parameters, including rectal digital examinations and serum PSA levels $(14,85)$.

Furthermore, nomograms have been developed to predict the pathological stage at radical prostatectomy, and disease progression after surgery or radiation therapy. The nomograms typically include pre-treatment variables as clinical stage, biopsy-based Gleason score, serum PSA, amount of cancer in needle biopsies, etc. In Sweden, based on three prognostic parameters the patients are divided into low, moderate and high risk groups (Table 9) (86).

\begin{tabular}{|l|c|c|c|c|}
\hline Risk group & $\begin{array}{c}\text { Preoperative } \\
\text { T category }\end{array}$ & PSA ng/ml & $\begin{array}{c}\text { Gleason } \\
\text { score }\end{array}$ & $\begin{array}{c}10 \text { years } \\
\text { cancer free } \\
\text { over living } \%\end{array}$ \\
\hline Low & T1c-T2a and & $<=10$ and & $<=6$ & 83 \\
\hline Intermediate & T2b or & $10-20$ or & 7 & 46 \\
\hline High & >=T2c or & $>20$ or & $>=8$ & 29 \\
\hline
\end{tabular}

Table 9. Risk groups of prostate cancer, based on the correlation between preoperative diagnostic parameters and 10-year cancer-free survival after RP according to D`Amico (87).

This risk allocation predicts life expectancy and is important for treatment planning. Recently, an increasing number of clinicians have started to require more pathological information (e.g. the number of positive biopsies, percentage of cancer tissue in all biopsies) for their therapeutic decisions. Nomograms are used with increasing frequency in clinical practice by urologists and radiation oncologists to counsel their patients regarding therapeutic options and the potential risk of failure based on the therapy they choose $(14,17,88)$.

The best-known algorithm to predict the pathologic stage of clinically localized prostate cancer is the Hamburg algorithm. This system categorizes patients into three risk groups for lymph node metastases based on the Gleason grade of a systematic sextant biopsy using classification and regression tree analysis $(89,90)$. Because of the anatomic location of the 
prostate gland, determination of the lymph node status is not easy. This is only possible with certain radiologic imaging techniques which have lower specificity and are more expensive than histological examination. In other organs such as the breasts, we can get an accurate picture of the lymph node status with the examination of the sentinel lymph nodes (91-97). Although sentinel lymphadenectomy has been pioneered in prostate cancer too and has been described as feasible and potentially allowing unexpected lymphatic drainage and metastatic spread to be discovered $(98,99)$, it has not gained wide acceptance. Briganti et al analysed corresponding prostate biopsy specimens with 278 consecutive prostatectomy specimens that included lymph node dissection (100). These authors concluded that the percentage of positive cores and biopsy Gleason score are the two most informative predictors of a positive lymph node status. They created a preoperative nomogram which had $83 \%$ accuracy for predicting lymph node status. The Briganti nomogram was recently validated by Heidenreich et al, who examined 499 biopsy-prostatectomy pairs and concluded that the percentage of positive cores was the most reliable predictor of lymph node metastases (101).

Our results also indicate that combining the number of positive cores with additional parameters as preoperative PSA level and biopsy Gleason score further improves the prediction of ECE. Preoperative PSA levels $<10 \mathrm{ng} / \mathrm{ml}$ in addition to Gleason score $<7$ and presence of cancer in no more than one core identified a low-risk patient group with no ECE observed in the present study. The opposite combination (preoperative PSA levels $>=10$ $\mathrm{ng} / \mathrm{ml}$ in addition to Gleason score $>=7$ and presence of cancer in more than one core) identified a group of patients with high risk (77\% probability, 10/13) of ECE. These results strongly support that the combination of the above mentioned parameters might be used in therapeutical decision making. 


\section{SUMMARY, CONCLUSIONS}

6.1 Our results confirm the previous observations that tumours with ductal differentiation are associated with adverse prognostic variables and outcome.

6.2 Our detailed immunohistochemical study demonstrated that the expression of p53, chromogranine A and EGFR in tumour cells of prostate cancer can differentiate tumours showing ductal differentiation from purely acinar cancers with reasonable accuracy. Assessing the expression of these biomarkers may represent not only useful ancillary diagnostic tools in prostate pathology, but could also predict a less favourable outcome.

6.3 Both 3-dimensional histology and the three selected biomarkers (combining chromogranine A, EGFR and p53) can help to accurately distinguish DAP from AAP. This discriminatory ability offers AAP cases less radical treatment regimens and emphasizes the need to develop more effective treatment regimens for DAP cases.

6.4 The results of the present study indicate that transrectal ultrasound-guided systematic, at least sextant needle biopsies can be used to assist the prediction of extracapsular disease at radical prostatectomy. Prostate sides giving no or only one PCa containing cores out of the three (sextant biopsy) or four (octant biopsy) are at a relatively low risk of having ECE compared with those containing two or three positive cores. Finding no more than one positive out of three or four cores available per side predicted the absence of extracapsular disease with a negative predictive value approaching $94 \%$.

6.5 Combining this information (see above under 6.4) with preoperative PSA level and biopsy Gleason score further enhances the predictive power for ECE. Such information is useful in planning nerve-preservation at RP. 


\section{ACKNOWLEDGEMENTS}

I thank my supervisor and previous boss, Professor Gábor Cserni, head of the Department of Pathology, Bács-Kiskun County Teaching Hospital Kecskemét for his support and scientific guidance of my work.

I wish to express my special thanks to my current boss, Professor Tibor Tot, head of the Department of Pathology and Clinical Cytology, Central Hospital, Falun, Sweden, who provided scientific guidance of my work and excellent working conditions for me.

Special thanks are due to Professor László Tabár, Professor Hsiu-Hsi Chen, Wendy Wu, Anna Lenngren, Peter B. Dean and Dan Hellberg who helped this dissertation to be born.

I greatly appreciate all the support and work of high standard provided by laboratory assistants of the Department of Pathology and Clinical Cytology, Central Hospital, Falun, Sweden without whom this task would never have been fulfilled.

I also thank my family and my parents for encouraging and supporting me. 


\section{REFERENCES}

1. IARC-International Agency for Research on Cancer, Cancer Mondial, Globocan 2008 database.

2. Greenlee RT, Hill-Harmon MB, Thum M. Cancer statistics CA Cancer J Clin 2001;51:1536.

3. Bahn DK, Lee F. Cryosurgical ablation therapy for prostate cancer. Arch Ital Urol Androl 2000;72:302-4.

4. Kiel HJ, Wieland WF, Rossler W. Local control of prostate cancer by transrectal HIFUtherapy. Arch Ital Urol Androl 2000;72:313-9.

5. Hayes DF, Bast RC, Desch CE, et al. Tumor marker grading system: a framework to evaluate clinical utility of tumor markers. J Natl Cancer Inst 1996;88:1456-66.

6. Bostwick DG, Grignon DJ, Hammond EH, et al. Prognostic factors in prostate cancer. College of American Pathologists consensus Statement 1999. Arch Pathol Lab Med 2000;124:995-1000.

7. Bostwick DG, Foster CS. Predictive factors in prostate cancer: current concepts from the 1999 College of American pathologists Conference on Solid Tumor Prognostic Factors and the 1999 World Health Organization Second International Consultation on Prostate Cancer. Semin Urol Oncol 1999;17:222-72.

8. Egevard L. Reproducibility of Gleason grading of prostate cancers can be improved by the use of reference images. Urology 2001;57:291-5.

9. Lewis. Jr JS, Vollmer RT, Humphrey PA. Carcinoma extent in prostate needle biopsy tissue in the prediction of whole gland tumor volume in a screening population. Am J Clin Pathol 2002;118:442-50.

10. Bismar TA, Lewis JS, Vollmer RT, et al. Multiple measures of carcinoma extent versus perineural invasion in prostate needle biopsy tissue in prediction of pathologic stage in a screening population. Am J Surg Pathol 2003;27:432-40.

11. Srigley JR, Amin MB, Bostwick DG, et al. Updated protocol for the examination of specimens from patients with carcinomas of the prostate gland. Arch Pathol Lab Med 2000;124:1034-9.

12. Stamey TA, McNeal JE, Freiha FS, et al. Morphometric and clinical studies on 68 consecutive radical prostatectomies. J Urol 1988;139:1235-41.

13. Ohori M, Wheeler TM, Kattan MW, et al. Prognostic significance of positive surgical margins in radical prostatectomy specimens. J Urol 1995;154:1818-24. 
14. Partin AW, Kattan MW, Subong EN, et al. Combination of prostate-specific antigen, clinical stage, and Gleason score to predict pathological stage of localized prostate cancer. A multi-institutional update. JAMA 1997;277:1445-51.

15. Cheng L, Slezak J, Bregstrall EJ, et al. Preoperative prediction of surgical margin status in patients with prostate cancer treated by radical prostatectomy. J Clin Ocol 2000;18:2862-8. 16. Bostwick DG, Qian J, Bergstrall EJ, et al. Prediction of capsular perforation and seminal vesicle invasion in prostate cancer. J Urol 1996;155:1361-7.

17. Gancarczyk KJ, Hongyu WU, Mc Leold DG, et al. Using the percentage of biopsy cores positive for cancer, pre-treatment PSA and highest biopsy Gleason sum to predict pathology stage after radical prostatectomy: The center for prostate disease research normograms. Urology 2003;61:589-95.

18. Sebo TJ, Bock BJ, Cheville JC, et al. The percent of cores positive for cancer in prostate needle biopsy specimens is a strongly predictive of tumor stage and volume at radical prostatectomy. J Urol 2001;163:174-8.

19. Samaratunga H, Duffy D, Yaxley J, et al. Any proportion of ductal adenocarcinoma in radical prostatectomy specimens predicts extraprostatic extension. Hum Pathol 2010;41:2815 .

20. Amin A, Epstein JI. Pathologic stage of prostatic ductal adenocarcinoma at radical prostatectomy: effect of percentage of ductal component and associated grade of acinar adenocarcinoma. Am J Surg Pathol 2011;35:615-9.

21. Epstein JI, Woodruff JM. Adenocarcinoma of the prostate with endometrioid features. A light microscopic and immunohistochemical study of ten cases. Cancer 1986;57:111-9.

22. Brinker DA, Potter SR, Epstein JI: Ductal adenocarcinoma of the prostate diagnosed on needle biopsy: correlation with clinical and radical prostatectomy findings and progression. Am J Surg Pathol 1999;23:1471-9.

23. Christensen WN, Steinberg G, Walsh PC, et al. Prostatic duct adenocarcinoma. Findings at radical prostatectomy. Cancer 1991;67:211.

24. Epstein JI. Prostatic ductal adenocarcinoma: A mini review. Med Princ Pract 2010;19:825 .

25. Bock BJ, Bostwick DG. Does prostatic ductal adenocarcinoma exist? Am J Surg Pathol 1999;23:781-5.

26. Goldstein NS. Immunophenotypic characterization of 225 prostate adenocarcinomas with intermediate or high Gleason scores. Am J Clin Pathol 2002;117:471-2. 
27. Ljung G, Norberg M, Holmberg L, et al. Characterization of residual tumor cells following radical radiation therapy for prostatic adenocarcinoma; immunohistochemical expression of prostate-specific antigen, prostatic acid phosphatase, and cytoceratin 8 . The Prostate 1997;31:91-7.

28. Bassily NH, Vallorosi CH, Akdas G, et al. Coordinate expression of cytokeratins 7 and 20 in prostate adenocarcinoma and bladder urothelial carcinoma. Am J Clin Pathol 2000;113: 383-8.

29. Krijnen JL, Bogdanowicz JF, Seldenrijk CA, et al. The prognostic value of neuroendocrine differentiation in adenocarcinoma of the prostate in relation to progression of disease after endocrin therapy. J Urol 1997;158: 171-4.

30. May M, Siegsmund M, Hammermann F, et al. Prognostic significance of proliferation activity and neuroendocrine differentiation to predict treatment failure after radical prostatectomy. Scand J Urol Nephrol 2007;41:375-81.

31. Tamas EF, Epstein JI. Prognostic significance of Paneth cell-like neuroendocrine differentiation in adenocarcinoma of prostate. Am J Surg Pathol 2006;30: 980-5.

32. Gerdes J, Lemke H, Baish $\mathrm{H}$, et al. Cell cycle analysis of cell proliferation-associated human nuclear antigen defined by monoclonal antibody Ki-67. Immunol 1984;133:1710-5.

33. Moul JW, Bettencourt MC, Sesterhenn IA, et al. Protein expression of p53, bcl-2 and Ki67 (MIB-1) as prognostic biomarkers in patients with surgically treated, clinically localized prostate cancer. Surgery 1996;120:159-66.

34. Stapleton AM, Zbell P, Kattan MW, et al. Assessment of the biologic markers p53, Ki-67 and apoptotic index as predictive indicators of prostate carcinoma recurrence after surgery. Cancer 1998;82:168-75.

35. Tot $\mathrm{T}$, Tabár L, Dean PB. The pressing need for better histologic-mammographic correlation of the many variations in normal breast anatomy. Virch Arch 2000;437:338-44.

36. Tot T, Tabár L Dean PB. Practical Breast Pathology Stuttgard-New York:Thieme 2002.

37. Tabár L, Tot T, Dean PB. Breast Cancer: The Art and Science of Early Detection with Mammography. Vol I. Perception, Interpretation, Histopathologic Correlation. Stuttgart: Thieme; 2005:pp 405-38.

38. Kastendieck H, Altenähr E, Hüsselmann H, et al. Carcinoma and dysplastic lesion of the prostate. A histomorphological analysis of 50 total prostatectomies by step-section technique. Z Krebsforsch Klin Onkol Cancer Res Clin Oncol 1976;88:33-54.

39. Cookson MS, Aus G, Burnett AL, et al. Variation in the definition of biochemical recurrence in patients treated for localized prostate cancer: the American Urological 
Association Prostate Guidelines for Localized Prostate Cancer Update Panel report and recommendations for a standard in the reporting of surgical outcomes. J Urol 2007;177:540-5. 40. Yang XJ, Cheng L, Helpap B, et al. Ductal adenocarcinoma. In: Eble JN, Sauter G, Epstein JI, Sesterhenn A. World Health Organization Classification of Tumours of the Urinary System and Male Genital Organs. Lyon: IARC Press, 2004.

41. Hanley JA, McNeil BJ. The meaning and use of the area under a receiver operating characteristic (ROC) curve. Radiology 1982;143:29-36.

42. Melicow MM, Pachter MR: Endometrial carcinoma of prostatic utricle (uterus masculinus). Cancer 1967;20:1715-22.

43. Young BW, Lagios MD. Endometrial (papillary) carcinoma of the prostatic utricleresponse to orchidectomy. A case report. Cancer 1973;32:1293-300.

44. Walker AN, Mills SE, Fechner RE, et al. "Endometrial" adenocarcinoma of the prostatic urethra arising in villous polyp. A light microscopic and immunoperoxidase study. Arch Pathol Lab Med 1982;106:624-7.

45. Bostwick DG, Kindrachuk RW, Rouse RV. Prostatic adenocarcinoma with endometrioid features. Clinical, pathological, and ultrastructural findings. Am J Surg Pathol 1985;9:595609.

46. Millar EK, Sharma NK, Lessells AM. Ductal (endometriod) adenocarcinoma of the prostate: clinocopathological study of 16 cases. Histopathology 1996;29:11-19.

47. Oxley JD, Abbott CD, Gillatt DA, et al. Ductal carcinomas of the prostate: clinicopathological and immunohistochemical study. Brit J Urol 1998;81:109-15.

48. Tu SM, Reyes A, Maa A, et al. Prostate carcinoma with testicular or penile metastases: clinical, pathologic, and immunohistochemical features. Cancer 2002;94:2610-7.

49. Orihuela E, Green JM. Ductal prostate cancer: Contemporary management and outcomes. Urol Oncol 2008;26:368-71.

50. Tavora F, Epstein JI. High-grade prostatic intraepithelial neoplasialike ductal adenocarcinoma of the prostate: Clinicopathologic study of 28 cases. Am J Surg Pathol 2008;32:1060-7.

51. Lotan TL, Toubaji A, Albadine R, et al. TMPRSS2-ERG gene fusions are infrequent in prostatic ductal adenocarcinomas. Mod Pathol 2009;22:359-65.

52. Tu SM, Lopez A, Leibovici D, et al. Ductal adenocarcinoma of the prostate: clinical features and implications after local therapy. Cancer 2009;115:2872-80.

53. Lee TK, Miller JS, Epstein JI. Rare histological patterns of prostatic ductal adenocarcinoma Pathology 2010;42:319-24. 
54. Morgan TD, Welty CJ, Vakar-Lopez F, et al. Ductal Adenocarcinoma of the prostate: Incrased mortality risk and decreased serum prostate specific antigen. J Urol 2010;184:23037.

55. Finamanti M, Antonelli A, Contessa $\mathrm{P}$, et al. Ductal carcinoma of the prostate: impact on survival and therapeutic controversies of rare tumor. Urologia 2011;78:283-7.

56. Meeks JJ, Zhao LC, Cashy J, et al. Incidence and outcomes of ductal carcinoma of the prostate in the USA: analysis of data from the Surveillance, Epidemiology, and End Results program. BJU Inter 2011;109:831-4.

57. Copeland JN, Amin MB, Humphrey PA, et al. The morphologic spectrum of metastatic prostate adenocarcinoma to the lung: special emphasis on histologic features overlapping with other pulmonary neoplasms. Am J Clin Pathol 2002;117:552-7.

58. Collina G, Reggiani C, Carboni G. Ductal carcinoma of the prostate metastatic to the skin. Pathologica 2011;103:50-1.

59. Tulunay O, Orhan $\mathrm{D}$, Baltaci $\mathrm{S}$, et al. Prostatic ductal adenocarcinoma showing bcl-2 expression. Int J Urol 2004;11:805-8.

60. Roznovanu SL, Amalinei C, Radulescu D. Molecular mechanisms in hormoneresistant prostate cance. Rev Med Chir Soc Med Nat Iasi 2005;109:577-83.

61. Yamada Y, Nakamura K, Aoki S, et al. An immunohistochemical study of chromogranin A and human epidermal growth factor-2 expression using initial prostate biopsy specimens from patiens with bone metastatic prostate cancer. BJU Int 2007;99:189-95.

62. Tu SM, Lin S-H, Logothetis CJ. Stem-cell origin of metastasis and heterogeneity in solid tumours. Lancet Oncol 2002;3:508-13.

63. Scholmm T, Iwers L, Kirstein $\mathrm{P}$, et al A Clinical significance of p53 alterations in surgically treated prostate cancer. Mod Path 2008;21:1371-8.

64. Sithanandam G, Anderson LM. The ERBB3 receptor in cancer and cancer gene therapy. Cancer gene Ther 2008;15:413-48.

65. Mimeault M, Batra SK. Recent advances on multiple tumorigenic cascades involved in prostatic cancer progression and targeting therapies. Carcinogenesis 2006;27:1-22.

66. Shah RB, Ghosh D, Elder JT. Epidermal growth factor receptor (ErbB1) expression in prostate cancer progression: correlation with androgen independence. Prostate 2006;66:143744.

67. Di Lorenzo G, Tortora G, D'Armiento FP, et al. Expression of epidermal growth factor receptor correlates with disease relapse and progression to androgen-independence in human prostate cancer. Clin Cancer Res 2002;8:3438-44. 
68. Weber DC, Tille JC, Combescure C, et al. The prognostic value of expression of HIF1alpha, EGFR and VEGF-A, in localized prostate cancer for intermediate- and high-risk patients treated with radiation therapy with or without androgen deprivation therapy. Radiat Oncol 2012;7:66.

69. Vuky J, Porter C, Isacson C, et al.: Phase II trial of neoadjuvant docetaxel and gefitinib followed by radical prostatectomy in patients with high-risk, locally advanced prostate cancer. Cancer 2009;115:784-91.

70. Bostwick DG. Practical clinical application of predictive factors in prostate cancer. A review with an emphasis on quantitative methods in tissue specimens. Analyt Quant Cytol Histol 2005;1998;20:323-42.

71. Revelos K, Petraki C, Gregorakis A, et al. P27(kip1) and Ki-67 (MIB-1) immunohistochemical expression in radical prostatectomy specimens of patients with a clinically localized prostate cancer. In Vivo 2005;19:911-20.

72. Vis A, Noordzij MA, Fitoz K, et al. Prognostic value of cell cycle proteins p27 (kip1) and MIB-1, and the celladhesion protein CD44s in surgically treated pateints with prostate cancer. J Urol 2000;164:2156-61.

73. Borre M, Stausbol-Gron B, Overgaard J. p53 accumulation associated with bcl-2, the proliferation marker MIB-1 and survival in patients with prostate cancer subjected to watchful waiting. J Urol 2000;164:716-21.

74. Moul JW. Angiogenesis, p53, bcl-2 and Ki-67 in the progression of prostate cancer after radical prostatectomi. Eur Urol 1999;35:399-407.

75. Bai XZ, Masters JR, O’Donoghue N, et al. Prognostic markers in clinically localised prostate cancer. Int J Oncol 1999;14:785-91.

76. Paulson DF, Moul JW, Walther PJ. Radical prostatectomy for clinical stage T1-T2N0M0 prostatic adenocarcinoma: Long-term results. J Urol 1990;144:1180-4.

77. Paulson DF. Impact of radical prostatectomy in management of clinically localized disease. J Urol 1994;152:1826-30.

78. Grossfeld GD, Chang JJ, Boering JM, et al. Understaging and undergrading in a contemporary series of patients undergoing radical prostatectomy: results from the Cancer of the Prostate Strategic Urologic Research Endeavor database. J Urol 2001;165:851-6.

79. Lee AK, Schultz D, Renshaw AA, et al. Patient selection for prostate monotherapy. Int J Radiat Oncol Phys 2001;49:673-7.

80. Ogawa O, Egawa S, Arai Y, et al. Preoperative predictors for organ cofined disease in Japanese patients with stage T1c prostate cancer. Int J Urol 1998;5:454-8. 
81. Gohji K, Okamoto M, Takenaka A, Nomi M, Fujii A. Predicting the extent of prostate cancer using the combination of systematic biopsy and serum prostate specific antigen in Japanese men. BJU Int 1999;83:39-42.

82. Peller PA, Young DC, Marmaduke DP, et al. Sextant prostate biopsies. A histopathologic correlation with radical prostatectomy. Cancer 1995;75:530-8.

83. Tigrani VS, Bhargava V, Sinohara K, et al. Number of positive systematic sextant biopsies predicts surgical margin status at radical prostatectomy. Urology 1999;54:689-93.

84. King CR, Patel DA, Terris MK. Prostate biopsy volume indices do not predict for significant Gleason upgrading. Am J of Clin Oncol 2005;28:125-9.

85. Amin M, Boccon-Gibod L, Egevad L, et al. Prognostic and predictive factors and reporting of prostate carcinoma in prostate needle biopsy specimens. Scand J Urol Nephrol Suppl. 2005;216:20-33.

86. Adding C, Nilsson A, Hosseini A, et al. Radikal prostatektomi - den botande kirurgiska behandlingen. Läkartidningen 2012;109:407-11.

87. D`Amico AV, Whittington R, Malkowicz SB, et al. Predicting prostate specific antigen outcome preoperatively in the prostate specific antigen era. J Urol 2001;166:2185-8.

88. Ohori M, Kattan MW, Koh H, et al. Predicting the presence and side of extracapsular extension: a nomogram for staging prostate cancer. J Urol 2004;171:1844-9.

89. Haese A, Epstein JI, Huland H, et al. Validation of biopsy-based pathologic algorithm for predicting lymph node metastases in patients with clinically localized prostate carcinoma. Cancer 2002;95:1016-21.

90. Conrad S, Graefen M, Pichlmeier U, et al. Systematic sextant biopsies improve preoperative prediction of pelvic lymph node metastases in patients with clinically localized prostatic carcinoma. J Urol 1998;159:2023-9.

91. Cserni G, Boross G, Baltás B. Value of axillary sentinel nodal status in breast cancer. World J Surg 2000;24:341-4.

92. Cserni G. Effect of increasing the surface sampled by imprint cytology on the intraoperative assessment of axillary sentinel lymph nodes in breast cancer patients. Am Surg 2003;69:419-23.

93. Cserni G, Amendoeira I, Apostolikas N, et al. Pathological work-up of sentinel lymph nodes in breast cancer. Review of current data to be considered for the formulation of guidelines. Eur J Cancer 2003;39:1654-67.

94. Cserni G. Pathological evaluation of sentinel lymph nodes. Surg Oncol Clin North Am 2007; 16:17-34. 
95. Cserni G, Bori R, Sejben I, et al. A hónalji nyirokcsomók további érintettségére vonatkozó modellek elemzése kisméretü ( $\leq 15 \mathrm{~mm}$ ) örszemnyirokcsomó-áttétes emlőrákokban. Orv Hetil 2009;150:2182-8.

96. Cserni G, Bori R, Maráz R, et al. Multi-institutional comparison of non-sentinel lymph node predictive tools in breast cancer patients with high predicted risk of further axillary metastasis. Pathol Oncol Res 2013;19:95-101.

97. Tarján M. Sentinel lymph node biopsy in Hungary. Results with a revolutionary new method in surgical oncology Magy Onkol 2002;46:315-21.

98. Wawroschek F, Vogt H, Weckermann D, et al. The sentinel lymph node concept in prostate cancer - first results of gamma probe-guided sentinel lymph node identification. Eur Urol 1999;36:595-600.

99. Varga J, Páczelt A, Tóth Z, et al. A prostata sentinel nyirokcsomója - a radikális prostatectomiát kísérő lymphadenectomia új szemlélete. Magyar Urológia 2001;13:145-50.

100. Briganti A, Karakiewicz PI, Chun FK, et al. Percentage of positive biopsy cores can improve the ability to predict lymph node invasion in patient $\mathrm{s}$ undergoing radical prostatectomy and external pelvic lymph node dissection. Eur Urol 2007;51:1573-81.

101. Heidenreich A, Pfister D, Thuer D, et al. Percentage of positive biopsies predict lymph node involvement in men with low-risk prostate cancer undergoing radical prostatectomy and extend pelvic lymphadenectomy. BJU Int 2011;107:220-5. 
SUPPLEMENTS

I. 